\title{
Sedimentology and sequence stratigraphy of paralic and shallow marine Upper Jurassic sandstones in the northern Danish Central Graben
}

\author{
Peter N. Johannessen
}

Paralic and shallow marine sandstones were deposited in the Danish Central Graben during Late Jurassic rifting when half-grabens were developed and the overall eustatic sea level rose. During the Kimmeridgian, an extensive plateau area consisting of the Heno Plateau and the Gertrud Plateau was situated between two highs, the Mandal High to the north, and the combined Inge and Mads Highs to the west. These highs were land areas situated on either side of the plateaus and supplied sand to the Gertrud and Heno Plateaus. Two graben areas, the Feda and Tail End Grabens, flanked the plateau area to the west and east, respectively. The regressive-transgressive succession consists of intensely bioturbated shoreface sandstones, $25-75 \mathrm{~m}$ thick. Two widespread unconformities $\left(\mathrm{SB}_{1}, \mathrm{SB}_{2}\right)$ are recognised on the plateaus, forming the base of sequence 1 and sequence 2 , respectively. These unconformities were created by a fall in relative sea level during which rivers may have eroded older shoreface sands and transported sediment across the Heno and Gertrud Plateaus, resulting in the accumulation of shoreface sandstones farther out in the Feda and Tail End Grabens, on the south-east Heno Plateau and in the Salt Dome Province. During subsequent transgression, fluvial sediments were reworked by high-energy shoreface processes on the Heno and Gertrud Plateaus, leaving only a lag of granules and pebbles on the marine transgressive surfaces of erosion $\left(\mathrm{MTSE}_{1}, \mathrm{MTSE}_{2}\right)$.

The sequence boundary $\mathrm{SB}_{1}$ can be traced to the south-east Heno Plateau and the Salt Dome Province, where it is marked by sharp-based shoreface sandstones. During low sea level, erosion occurred in the southern part of the Feda Graben, which formed part of the Gertrud and Heno Plateaus, and sedimentation occurred in the Norwegian part of the Feda Graben farther to the north. During subsequent transgression, the southern part of the Feda Graben began to subside, and a succession of backstepping back-barrier and shoreface sediments, $90 \mathrm{~m}$ thick, was deposited. In the deep Tail End and Feda Grabens and the Salt Dome Province, sequence boundary $\mathrm{SB}_{2}$ is developed as a conformity, indicating that there was not a significant fall in relative sea level in these grabens, probably as a result of high subsidence rates. Backstepping lower shoreface sandstones overlie $\mathrm{SB}_{2}$ and show a gradual fining-upwards to offshore claystones that are referred to the Farsund Formation. On the plateaus, backstepping shoreface sandstones of sequence 2 are abruptly overlain by offshore claystones, indicating a sudden deepening and associated cessation of sand supply, probably caused by drowning of the sediment source areas on the Mandal, Inge and Mads Highs. During the Volgian, the Gertrud Plateau began to subside and became a graben. During the Late Kimmeridgian - Ryazanian, a long-term relative sea-level rise resulted in deposition of a thick succession of offshore claystones forming highstand and transgressive systems tracts on the Heno Plateau, and in the Gertrud, Feda and Tail End Grabens.

Keywords: North Sea, Danish Central Graben, Kimmeridgian, sedimentology, sequence stratigraphy, ichnology, back-barrier - shoreface sediments, palaeogeography, sand distribution

Geological Survey of Denmark and Greenland, Geocenter Copenhagen, Øster Voldgade 10, DK-1350 Copenhagen K, Denmark. E-mail: pjo@geus.dk 


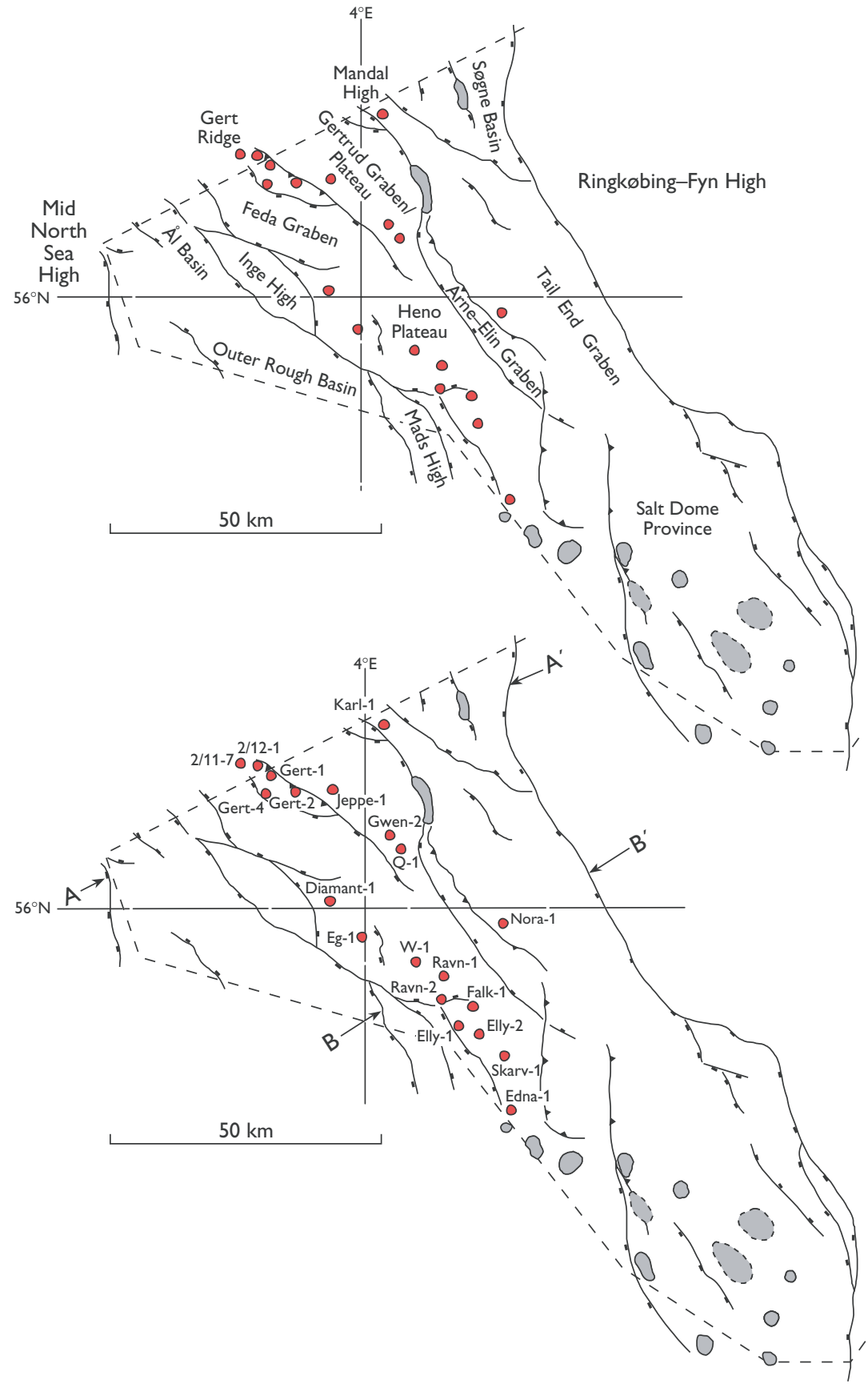

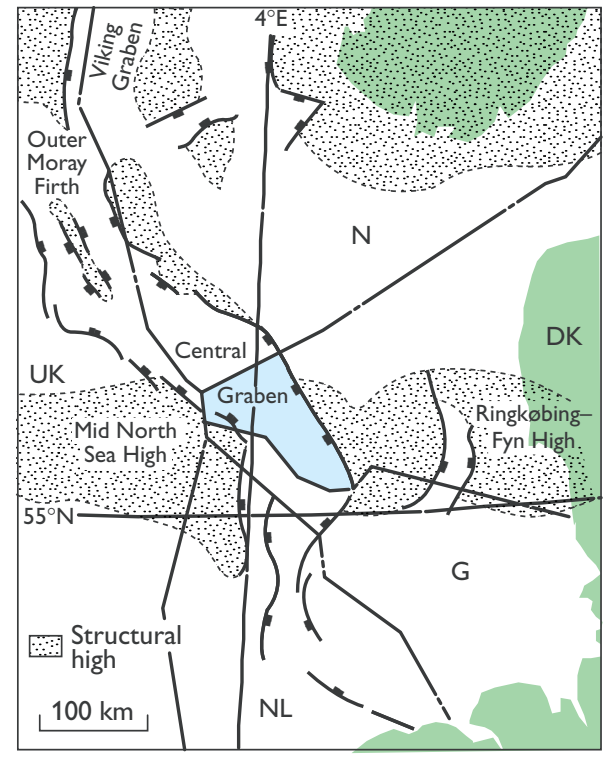

- Salt structures

- Normal fault

Reverse fault

- Well
Fig. 1. Maps showing the regional location and structural framework of the Danish Central Graben and the locations of wells and geosections (A- $\mathbf{A}^{\prime}, \mathbf{B}-\mathbf{B}^{\prime}$; Fig. 2) in the northern part of the graben. National sectors of the North Sea: DK, Denmark; G, Germany; $\mathbf{N}$, Norway; NL, the Netherlands; UK, United Kingdom.
Kimmeridgian shoreface sandstones form thick (25-200 m), widespread units in the North Sea Central Graben and constitute good reservoirs in the UK sector (Fulmar Formation; Fife, Clyde, and Fulmar Fields) and in the Norwegian sector (Ula Formation; Ula and Gyda Fields). In the Danish sector of the Central Graben, two fields are found: the Gert/Mjølner oil field and the Elly gas field, which are expected to start producing in the near future. In order to locate additional hydrocarbon fields with similar reservoir sandstones, it is of major importance to understand the distribution of the sandstones and their architecture.

The reservoir sandstones in most of the study area are deeply buried (3.5-5 km below mean sea level (b. msl)), resulting in limited seismic resolution. Furthermore, a large number of closely-spaced faults in the area render it difficult to trace seismic reflectors. In general, the biostratigraphic resolution is too poor to resolve correlations within the Kimmeridgian sandy successions; a sequence stratigraphic study based on cores and 

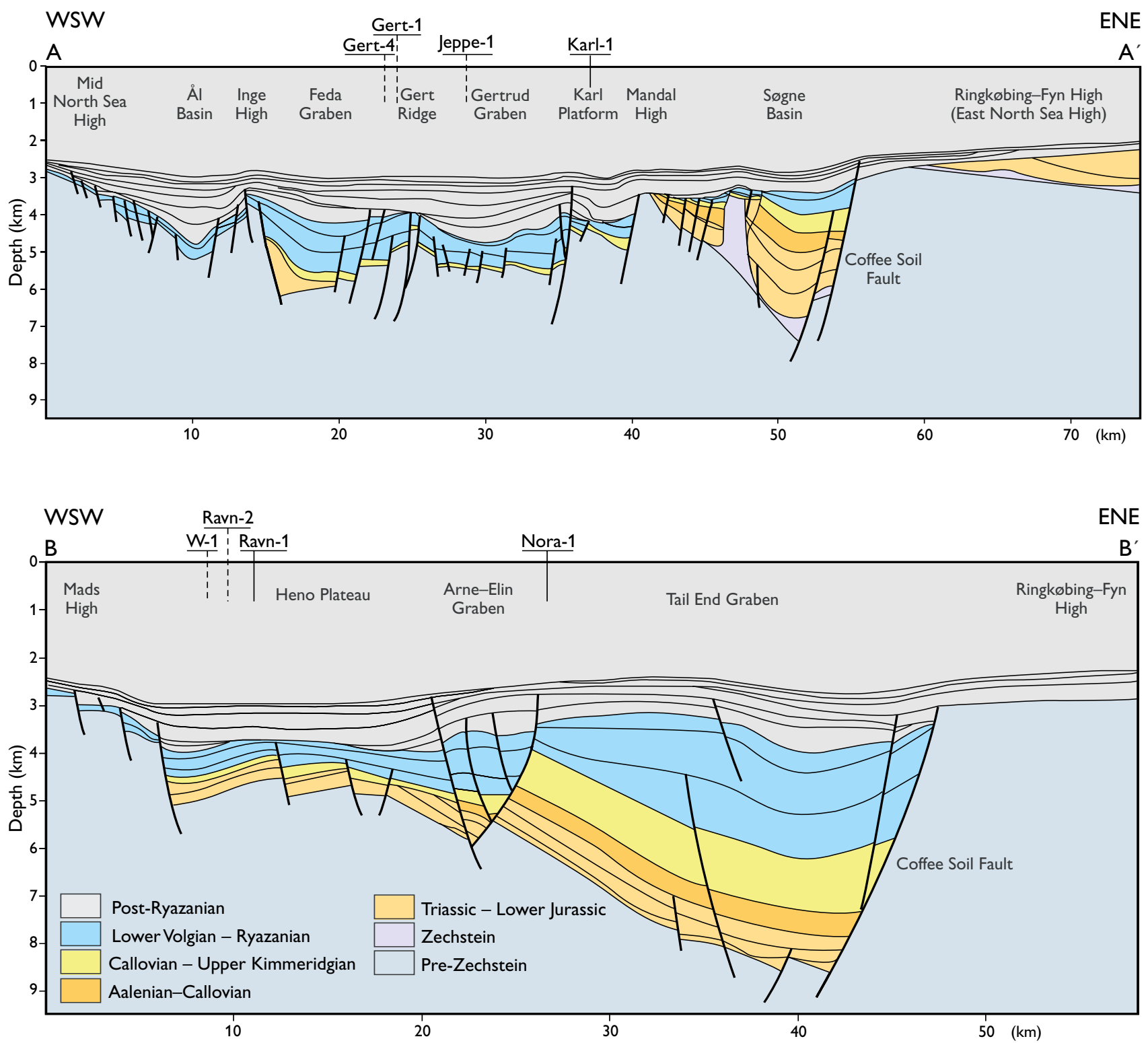

Fig. 2. Geosections oriented perpendicular to the axis of the Danish Central Graben. For location, see Fig. 1. The locations of wells used in this study that lie on or adjacent to the geosections are indicated; the well traces shown with solid lines are on the section line, those shown by dashed lines are projected into the line of section. Modified from Møller \& Rasmussen (2003, this volume).

petrophysical logs has thus been undertaken. All available cores were described and interpreted sedimentologically, including a detailed study of trace fossils and ichnofabric (Johannessen 1995). Petrophysical logs and cuttings samples were interpreted by comparison with the cored sections. North Sea Boreal age/stage terminology (sensu gallico) has been used throughout the paper.

The aim of this paper is to describe and interpret the depositional environments of the Kimmeridgian sediments on the Gertrud and Heno Plateaus, in the Tail
End and Feda Grabens and in the Salt Dome Province. The results of a detailed sequence stratigraphic analysis are presented as a series of log-panels and palaeogeographic maps and the potential distribution of further reservoir sandstones is discussed.

\section{Geological setting}

The Danish part of the North Sea Central Graben is bordered by the Mid North Sea High to the west and 


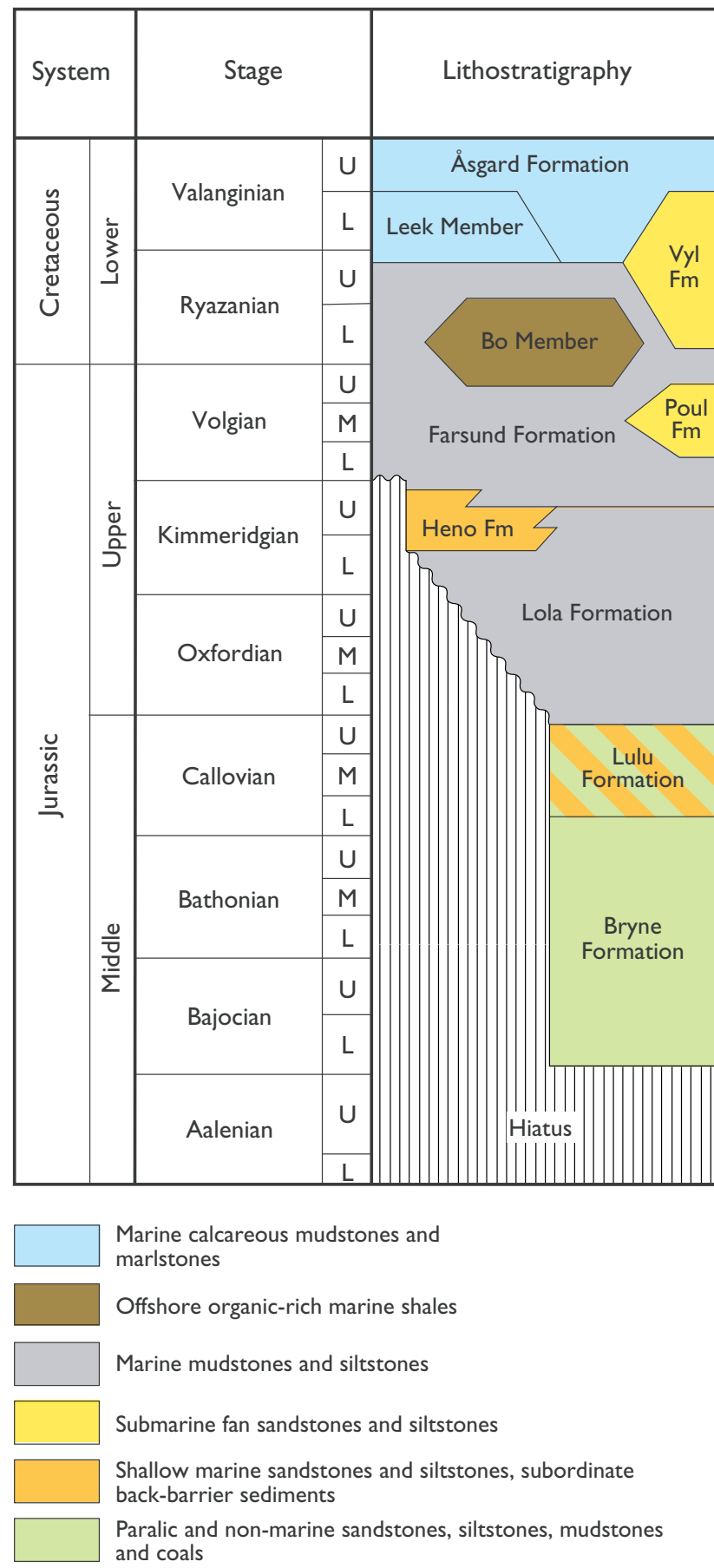

Fig. 3. Middle Jurassic - lowermost Cretaceous stratigraphic scheme for the Danish Central Graben. Modified from Michelsen et al. (2003, this volume).

the Ringkøbing-Fyn High to the east (Fig. 1). The central part of the area is dominated by the deep Tail End Graben, which is the main Jurassic depocentre with more than $4 \mathrm{~km}$ of primarily Upper Jurassic sediments
(Fig. 2; Jensen et al. 1986; Damtoft et al. 1992; Johannessen \& Andsbjerg 1993; Andsbjerg \& Dybkjær 2003, this volume; Japsen et al. 2003, this volume; Møller \& Rasmussen 2003, this volume).

The Middle Jurassic succession thickens eastwards towards the main fault against the Ringkøbing-Fyn High, suggesting that Middle Jurassic sediments were deposited during the early phase of half-graben subsidence (Damtoft et al. 1992; Johannessen \& Andsbjerg 1993; Andsbjerg 2003, this volume; Andsbjerg \& Dybkjær 2003, this volume). Rift-related subsidence within the Danish portion of the Central Graben is believed to have started in the Bajocian and the half-graben continued to subside until the Ryazanian (Fig. 3). During the Bajocian-Volgian, four major half-graben systems were formed and each new half-graben propagated farther westwards (Fig. 2; Damtoft et al. 1992). From east to west, these half-graben systems are termed the Søgne Basin - Tail End Graben - Salt Dome Province trend, the Gertrud Graben, and the Ål Basin - Outer Rough Basin trend (Fig. 1). The Feda Graben is an exception to this westward propagation, in that its northern part probably started to subside during Middle Jurassic times (Damtoft et al. 1992; Rasmussen 1995).

It has been proposed earlier that the overall Jurassic transgression proceeded from south to north through the Central Graben towards the triple junction dome (Eynon 1981; Koch 1983). More recently, however, on the basis of more extensive core data and better biostratigraphic data, it has been suggested that the transgression came from the north (Johannessen \& Andsbjerg 1993). During Late Jurassic time, after transgression of the deepest part of the incipient half-graben system, the rest of the Danish Central Graben was transgressed from the east towards the west (Fig. 3), with the exception of certain of the intrabasinal highs - the Mandal, Inge and Mads Highs (Damtoft et al. 1992; Johannessen \& Andsbjerg 1993).

The Heno Plateau is a complex block-faulted platform area with a much thinner Jurassic succession than in the graben areas, generally less than $1000 \mathrm{~m}$ thick (Fig. 2). Water depths during the Late Kimmeridgian were particularly shallow in the northern and central parts of the Heno Plateau (Diamant-1, Eg-1, Ravn-1, -2, W-1). Farther to the south-east (Elly-1, -2, Falk-1, Skarv-1), the Heno Plateau experienced a higher degree of subsidence resulting in increased accommodation space and greater water depths. Thus, although structurally forming part of the plateau area, the depositional environments tended towards those of the deeper graben areas such as the Tail End Graben and the Salt Dome Province lying 
east and south-east of the Heno Plateau (Figs 1, 2). On the Mads High, Upper Cretaceous chalk unconformably overlies Palaeozoic rocks (Damtoft et al. 1992). The Inge and Mads Highs formed a continuation of the Mid North Sea High during Bajocian-Kimmeridgian times, and constituted a large positive area that possibly was an important sediment source area (Johannessen et al. 1996).

During the Oxfordian and Kimmeridgian, the Gertrud Plateau and the Heno Plateau together formed a flatlying, slowly subsiding platform (Fig. 1; Söderström et al. 1991; Rasmussen 1995; Johannessen et al. 1996). The Gertrud Graben (previously the site of the Gertrud Plateau) did not begin to subside significantly before the Volgian. The Mandal High, which straddles the NorwegianDanish border east of the Gertrud Plateau and becomes pronounced in the Norwegian sector farther north, may have been an important source area for the Upper Jurassic sandstones (Figs 1, 2).

During the Late Kimmeridgian and Volgian, a longterm relative sea-level rise resulted in deposition of thick offshore claystones in the central part of the Central Graben (Heno Plateau and Gertrud and Feda Grabens; Damtoft et al. 1992; Johannessen \& Andsbjerg 1993; Johannessen et al. 1996). During the Volgian and Early Cretaceous, the transgression continued towards the west, and shallow marine sandstones may have been deposited in the Outer Rough Basin and Ål Basin at the western margin of the Central Graben fringing the Mid North Sea High (Figs 1-3), as seen in the adjacent UK sector ('Fife sandstones'; Mackertich 1996; Spathopoulos et al. 2000).

\section{Regional stratigraphy}

The Upper Jurassic succession of the Danish Central Graben consists of the Lola, Heno, Farsund and Poul Formations (Figs 3, 4; Vollset \& Doré 1984; Jensen et al. 1986; Michelsen et al. 2003, this volume). The Lola Formation occurs in the southern part of the Gertrud and Heno Plateaus and in the Tail End Graben and is characterised by offshore claystones. It is mainly of Oxfordian age but extends up into the Upper Kimmeridgian in the Feda Graben (see below).

The Heno Formation is Kimmeridgian in age and is characterised by shoreface sandstones showing an overall regressive to transgressive pattern on the Heno and Gertrud Plateaus. In the deeper parts of the south-eastern Heno Plateau, the Feda Graben and the Salt Dome Province, the shoreface sandstones become more finegrained, consisting of overall regressive to transgressive clayey shoreface sandstones. Shoreface sandstones are not seen in wells in the Tail End Graben. The 'basal sandstone unit', and the Lola and Heno Formations have been described previously from the Feda Graben and Gertrud Plateau area (Bergan et al. 1989; Söderström et al. 1991; Johannessen et al. 1996). In the Danish sector, the back-barrier and shoreface sediments previously referred to the 'basal sandstone unit' are redefined in this volume as the Gert Member of the Heno Formation (Fig. 4); the shoreface sandstones classically referred to the Heno Formation (Jensen et al. 1986; Johannessen et al. 1996) are referred to the Ravn Member of the Heno Formation (Michelsen et al. 2003, this volume). New biostratigraphical data show that the Lola Formation on the Heno Plateau, the southern part of the Gertrud Plateau and in the Tail End Graben is not younger than Early Kimmeridgian (Cymodoce Chronozone; Andsbjerg \& Dybkjær 2003, this volume). However in the Gert area, where Lola Formation mudstones occur sandwiched between the Gert and Ravn Members of the Heno Formation (Fig. 4), the succession is no older than Late Kimmeridgian (Mutabilis Chronozone; Johannessen et al. 1996). Consequently, the offshore claystones referred to the Lola Formation in the Gert area are not age-equivalent with the Lola Formation on the Heno Plateau, as previously suggested (Johannessen \& Andsbjerg 1993).

The Farsund Formation is of Late Kimmeridgian Early Ryazanian age and consists of offshore claystones that are widespread in the Danish Central Graben, although absent over certain intra-basinal highs. The Poul Formation (Volgian) is recognised in the eastern part of the Tail End Graben, where it consists of turbidite sandstones (Jensen et al. 1986; Damtoft et al. 1992); this unit is not described further in this paper.

Regionally in the Central Graben, the Lola Formation correlates with the Haugesund Formation (Norway) and the Heather Formation (UK sector; Jensen et al. 1986). The Heno Formation is roughly equivalent to the Fulmar Formation in the UK sector (Johnson et al. 1986; Armstrong et al. 1987; Donovan et al. 1993; Partington et al. 1993; Price et al. 1993; Wakefield et al. 1993) and shows similarities with the 'Heno equivalent' and the Ula Formation of the Norwegian sector (Bergan et al. 1989; Taylor \& Gawthorpe 1993; Howell et al. 1996). The Farsund Formation correlates with the Kimmeridge Clay Formation of the UK sector and the Farsund Formation of the Norwegian sector (Vollset \& Doré 1984; Jensen et al. 1986). 


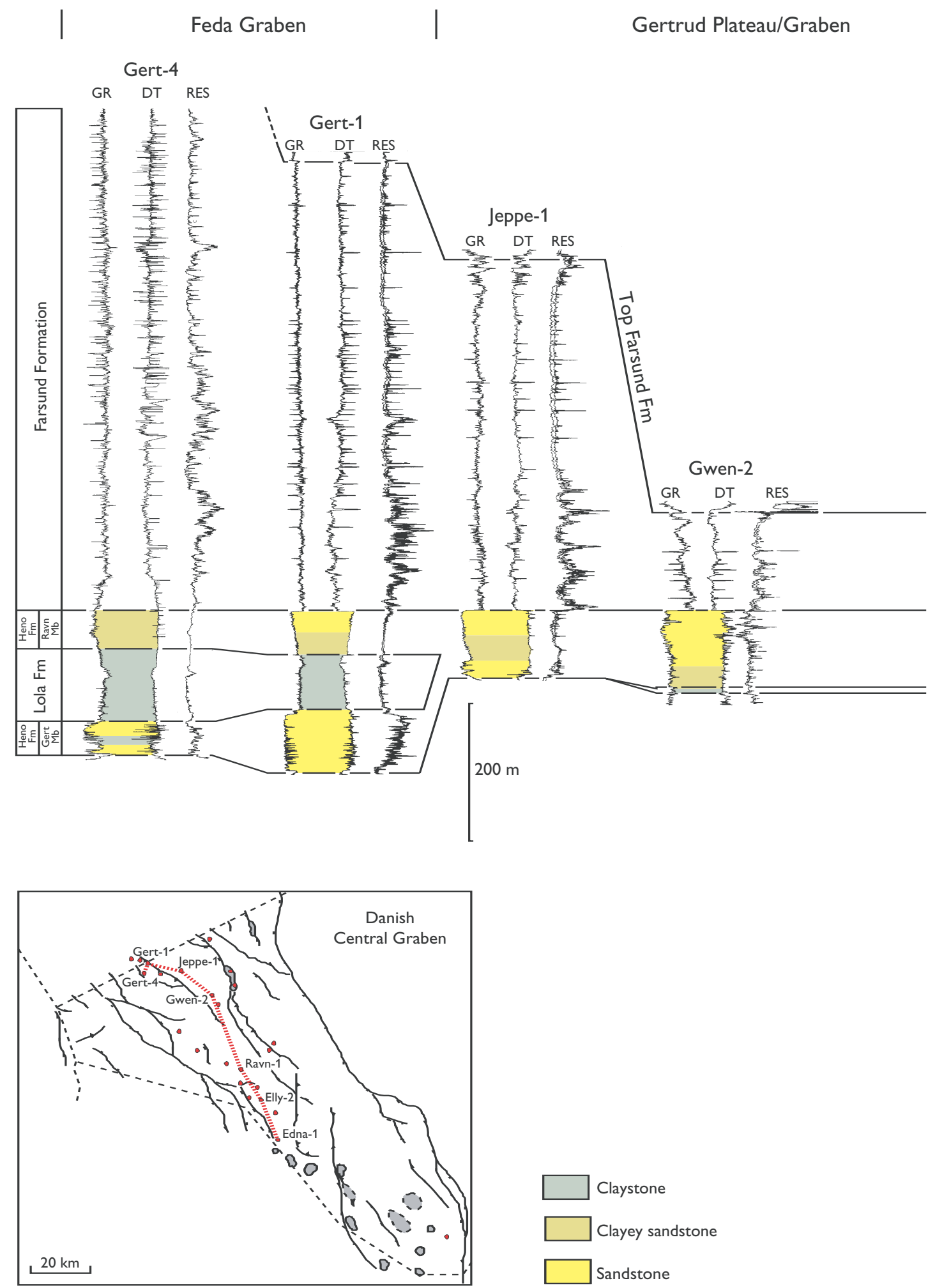

Fig. 4. Correlation of the Upper Jurassic - lowermost Cretaceous formations in the northern part of the Danish Central Graben, illustrated by gamma-ray (GR), sonic velocity (DT) and resistivity (RES) logs. The Gert and Ravn Members of the Heno Formation are defined in Michelsen et al. (2003, this volume). B. Fm, Bryne Formation. 


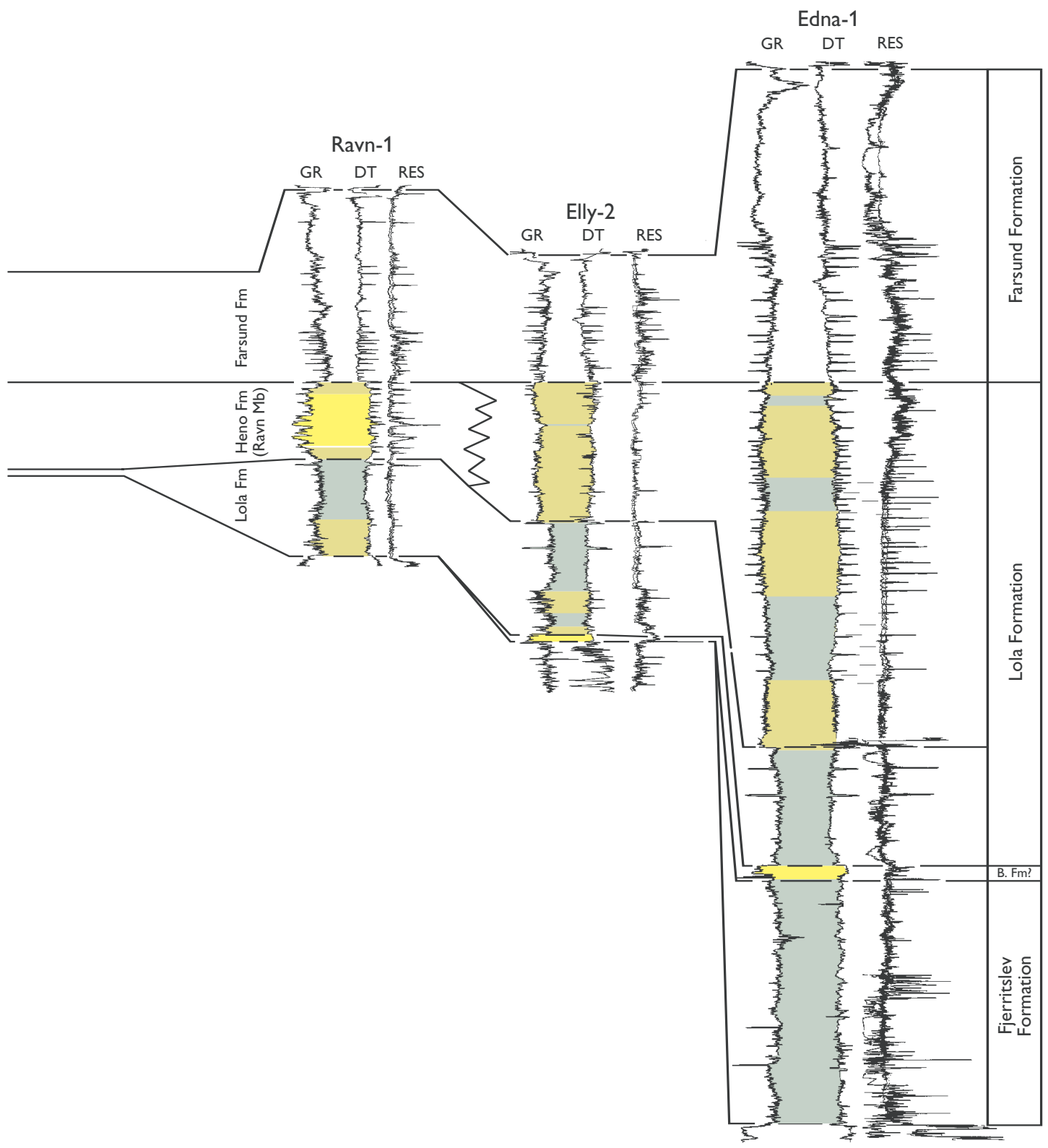



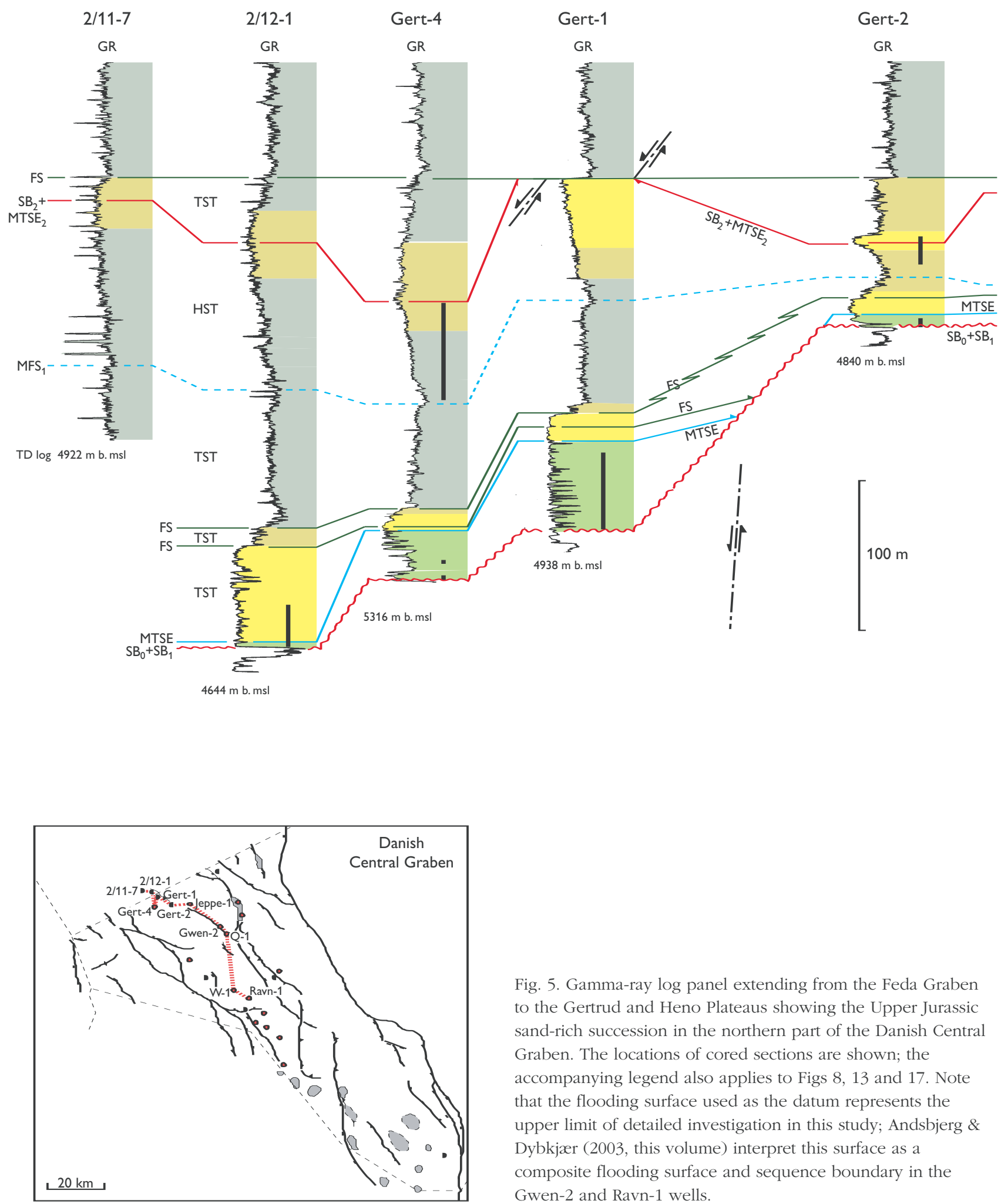

Fig. 5. Gamma-ray log panel extending from the Feda Graben to the Gertrud and Heno Plateaus showing the Upper Jurassic sand-rich succession in the northern part of the Danish Central Graben. The locations of cored sections are shown; the accompanying legend also applies to Figs 8, 13 and 17. Note that the flooding surface used as the datum represents the upper limit of detailed investigation in this study; Andsbjerg \& Dybkjær (2003, this volume) interpret this surface as a composite flooding surface and sequence boundary in the Gwen-2 and Ravn-1 wells. 


\section{Gertrud Plateau}

I Heno Plateau

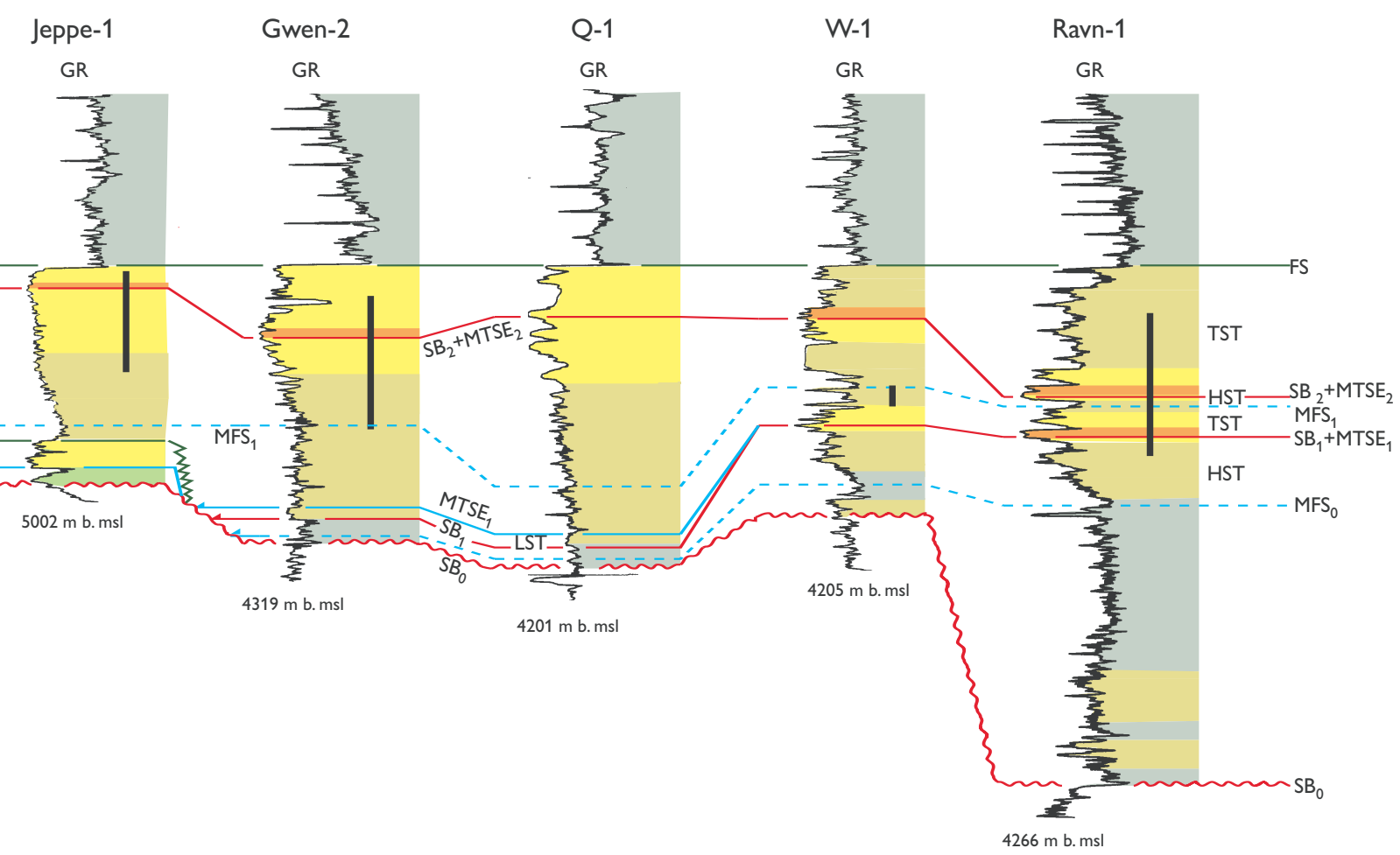

Sedimentary environments

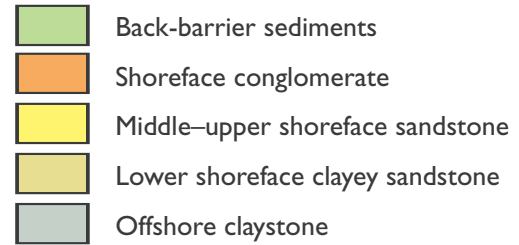

Systems tracts

LST Lowstand systems tract

TST Transgressive systems tract

HST Highstand systems tract
Key surfaces

\begin{tabular}{ll}
$\mathrm{SB}_{0}$ & Sequence boundary, Base Jurassic unconformity \\
MTSE & Marine transgressive surface of erosion \\
$\mathrm{SB}_{1}$ & Sequence boundary of sequence 1 \\
$-----\mathrm{MFS}_{1}$ & Maximum flooding surface in sequence 1 \\
\hline FS & Flooding surface \\
& Onlap
\end{tabular}

Additional features

$\begin{array}{ll}\text { TD } & \text { Core } \\ & \text { Casing point } \\ & \text { Bose Jurassic, metres below mean sea level } \\ & \text { Total Depth }\end{array}$




\section{Facies and depositional environments}

Three broad lithofacies associations have been recognised: offshore claystones, back-barrier sediments and shoreface sandstones (see Johannessen 1995 for detailed facies descriptions). These are described and interpreted briefly here in terms of four recurrent elements that form the building blocks of the sequence stratigraphic framework: (1) offshore claystones, (2) transgressive back-barrier to shoreface deposits, (3) regressive-transgressive shoreface sandstones and conglomerates and (4) sharp-based lower shoreface sandstones.

\section{Offshore claystones}

\section{Description}

The offshore claystones are characterised by high gamma-ray values, high resistivity readings and low sonic velocities (Fig. 4). Cuttings samples show that the claystones are associated with thin dolomite, sandstone and siltstone beds, and also that the organic content is variable. The claystones of the Lola Formation contain larger amounts of terrestrially-derived material than those of the Farsund Formation (Jensen et al. 1986; Michelsen et al. 1987). The claystones contain abundant and high diversity dinoflagellate assemblages.

\section{Interpretation}

The abundant dinoflagellates indicate that the claystones were deposited in a fully marine offshore setting. The claystones of the Lola Formation were probably deposited nearer to the sediment source area than those of the Farsund Formation, indicating an overall transgressive trend (Jensen et al. 1986; Michelsen et al. 1987).

\section{Transgressive back-barrier deposits to shoreface sandstones}

\section{Description}

The lowermost $56 \mathrm{~m}$ of the Upper Jurassic section were cored in Gert-1, situated in the eastern part of the Feda Graben near the Gertrud Plateau (Figs 5-7). The sec-

\section{Lithology}

\begin{tabular}{|c|c|}
\hline $\begin{array}{lll}0 & 0 & 0 \\
0 & 0\end{array}$ & Conglomerate \\
\hline 0 & Outsized quartz clast \\
\hline & Sandstone \\
\hline$==$ & Silt-claystone \\
\hline : & Heterolith \\
\hline & Coal \\
\hline $\mathbf{m}$ & Coal clast \\
\hline * & Pyrite \\
\hline
\end{tabular}

Sedimentary structures

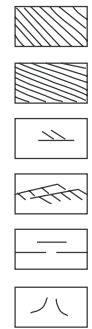

Cross-bedding

Low-angle cross-bedding

Cross-lamination

Climbing ripple cross-lamination

Faint parallel lamination

Water escape structure
Biogenic structures/components

Asterosoma isp.
Chondrites isp.
Piplocraterion isp.
Planolites isp.
Relithos isp.
Teichichnus isp.
Terebellina isp.
Thalassinoides isp.
Escape trace
Rootlets
Bivalve shell

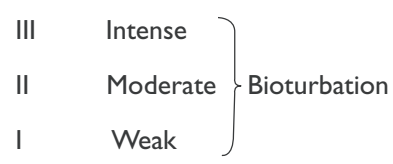

Additional features

Fig. $I$ Core photos

A $I$ Blow up of sedimentological log

MTSE Marine transgressive surface of erosion

SB Sequence boundary

MFS Maximum flooding surface

TST Transgressive systems tract

HST Highstand systems tract

Facing page:

Fig. 6. Sedimentological core log from sequence 1 in the Gert-1 well, located in the Feda Graben near the Gertrud Plateau. Typical small-scale coarsening-upwards to fining-upwards successions recognised in the cored section are illustrated in the enlarged logs (A, B). The accompanying legend (above) also applies to Figs 9 and 11. 

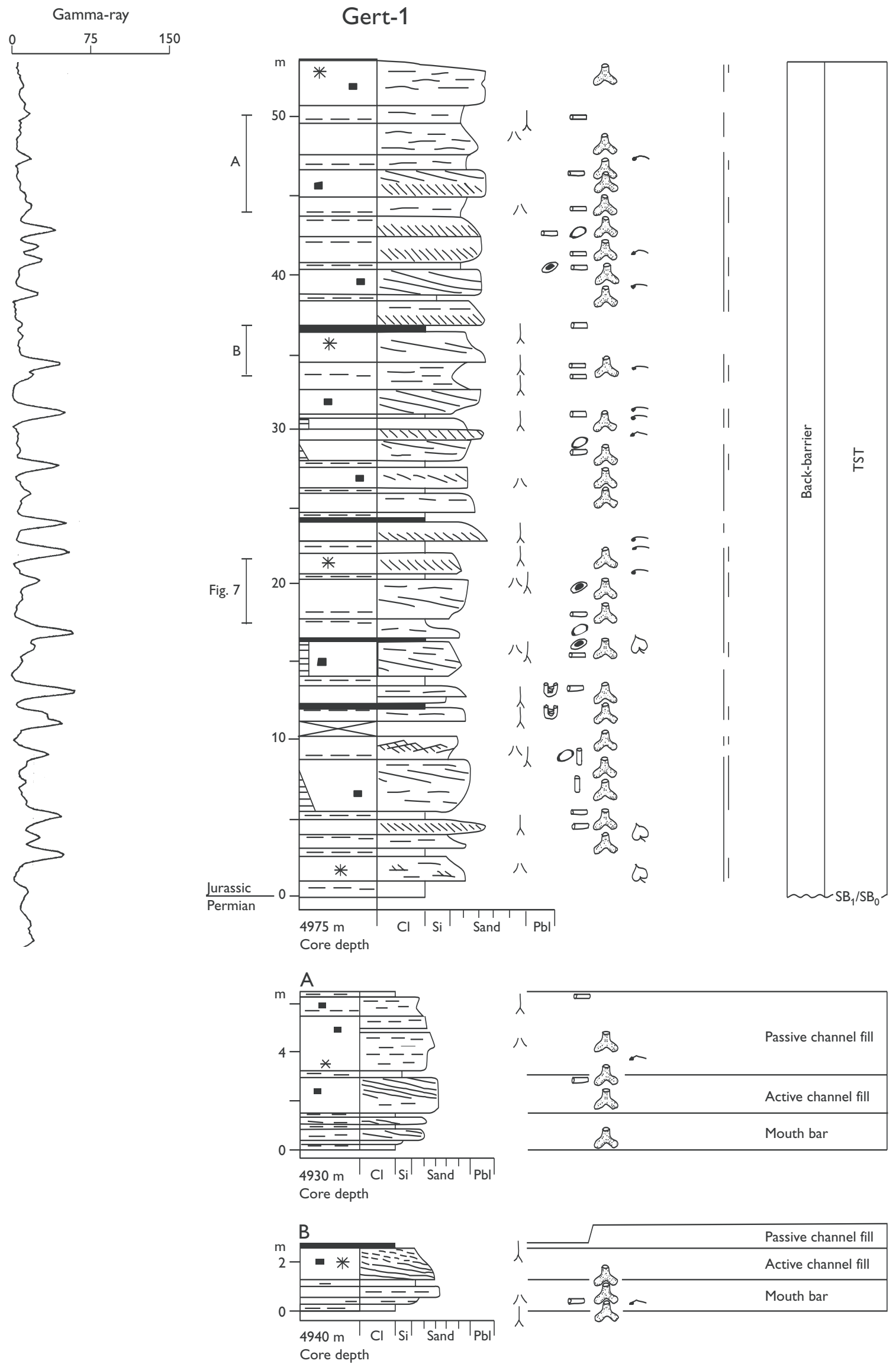


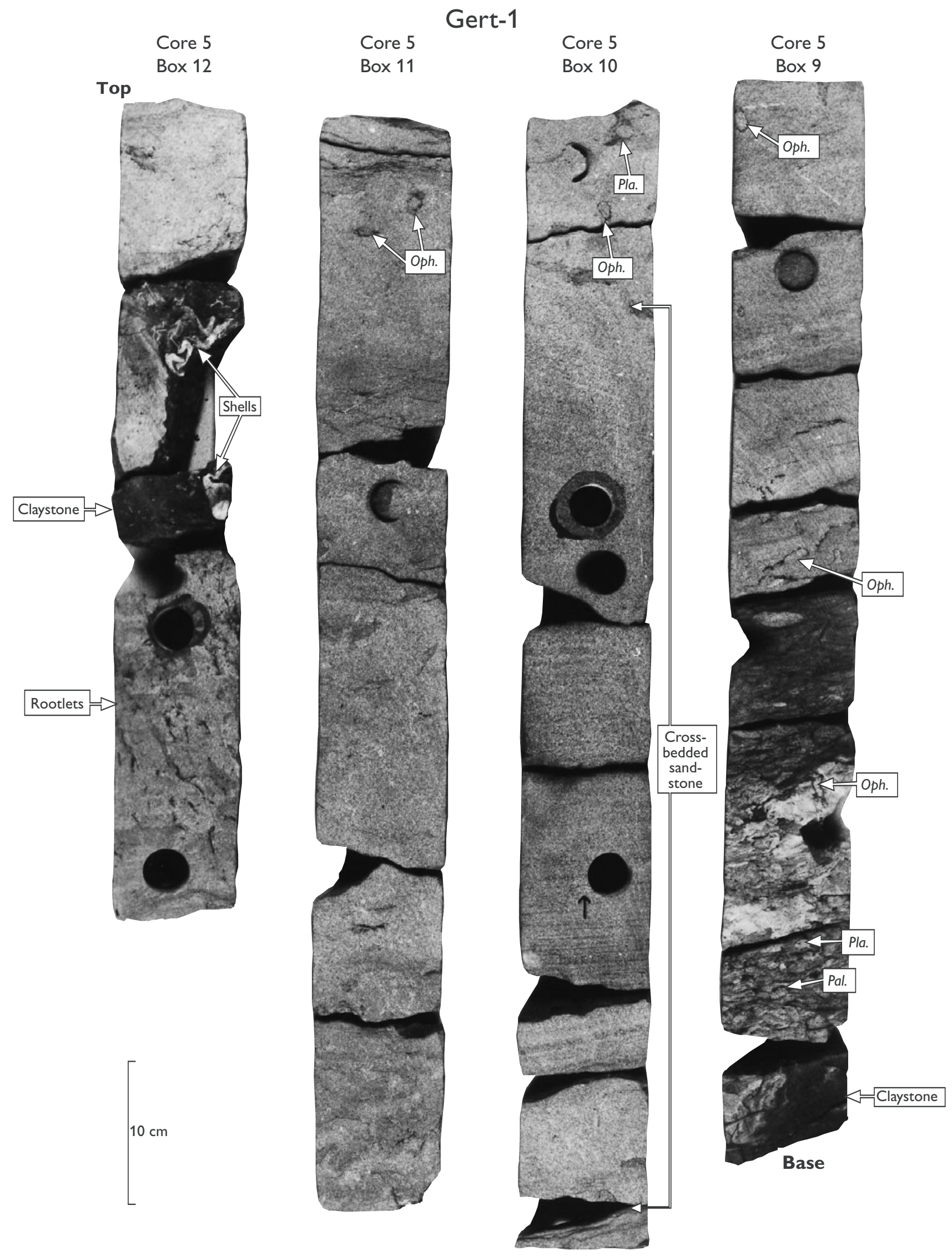


tion comprises interbedded fine-grained sandstones and claystones with coal beds, $2-15 \mathrm{~cm}$ thick. The fine-grained sandstones are typically so intensively bioturbated and affected by water-escape structures that all primary sedimentary structures are destroyed. Numerous burrows of Ophiomorpha nodosa as well as rootlets and coal fragments are recognised throughout the cored section (Figs 6, 7). Burrows of Palaeophycus isp., Diplocraterion isp., Terebellina isp., Skolithos isp. and Planolites isp. also occur.

The organic matter in the sandstone beds is solely composed of black, oxidised wood particles. The organic matter in the claystone beds and laminae is strongly dominated by terrestrially-derived particles, such as brown and black wood, cuticles, spores and pollen. Marine dinoflagellate cysts are present but are scarce in most samples (0-3\% of total palynomorphs); Carboniferous spores and pollen occur abundantly (Johannessen et al. 1996). Coarsening- to fining-upwards successions, 3-8 m thick, are recognised (Figs 6, 7). The lower, coarseningupwards portion consists mainly of Ophiomorpha-burrowed siltstones and fine-grained sandstones showing faint parallel bedding or low-angle cross-bedding, usually associated with water escape structures. The overlying fining-upwards portion is characterised by high-angle cross-bedded or low-angle cross-bedded fine-grained or medium-grained sandstones, overlain by structureless fine-grained sandstones, siltstones and claystones, in places capped by coal beds, $2-15 \mathrm{~cm}$ thick. The fining-upwards succession is usually associated with Ophiomorpha nodosa burrows, water escape structures and rootlets.

\section{Facing page:}

Fig. 7. Core photo from sequence 1 of Gert-1. Bioturbated heterolithic sandstones overlie claystones and are in turn overlain by faintly parallel-laminated, fine-grained sandstones with burrows of Ophiomorpha nodosa (Oph.). Cross-bedded fine-grained sandstones overlie the faint parallel-laminated sandstones. Claystones with thick bivalve shells overlie the sandstones. The upper part of the sandstone unit, immediately below the claystones, has numerous rootlets. The coarseningupwards heterolithic sandstones and the faint parallellaminated sandstones represent a mouth bar deposited in a back-barrier setting, probably near a bayhead delta. The overlying cross-bedded sandstones were deposited in a distributary channel, cutting through its own mouth bar. The uppermost claystones with underlying rootlets represent the final abandonment of the channel. For position of core photo, see Fig. 6. Additional trace fossils: Pal., Palaeophycus heberti; Pla., Planolites isp.
The lowermost $60 \mathrm{~m}$ thick section of Gert- 1 is characterised by a serrated gamma-ray log pattern (Fig. 5). Above this serrated interval is a unit (18 m thick) with consistently low gamma-ray readings, suggesting cleaner and probably more coarse-grained sandstones than below. A succession of very fine-grained sandstones, $6 \mathrm{~m}$ thick, overlies the clean, coarser-grained sandstones and is characterised by higher gamma-ray readings. The fine-grained sandstone unit is overlain by offshore claystones showing high gamma-ray values (Fig. 5).

\section{Interpretation}

A marginal marine setting is indicated by the association of rootlets and in situ coals, together with bioturbated sediments containing Ophiomorpha nodosa. The numerous water escape structures indicate rapid deposition. The nature of the kerogen indicates a low-salinity, nearshore setting with a high input of terrestrial material and the small number of dinoflagellate cysts, and the dominance amongst these of a single genus (Sentusidinium), indicates a low salinity, highly-stressed environment (Noe-Nygaard et al. 1987; Smelror \& Leereveld 1989). The association of restricted marine environments indicates that the sediments were deposited within a back-barrier setting.

The coarsening-upwards successions were probably deposited by prograding mouth bars, near the bayhead shoreline. The fining-upwards successions were deposited in channels by migrating mega-ripples or bars. The overlying fine-grained sandstones, siltstones and claystones represent the passive channel fill. The thin coal beds with rootlets, represent the final phase of abandonment. The occurrence of Ophiomorpha nodosa in sandstones of the passive channel fill may indicate some marine influence. The channels are interpreted as distributary channels that dissected their previously deposited mouth bars.

The general log motifs above the cored section in Gert-1 suggest a cleaner sandstone unit abruptly overlying the back-barrier sediments indicating that it was deposited under high-energy conditions. Further, the abundant dinoflagellate cysts in the overlying claystone suggest deposition in a fully marine offshore environment. Hence, the clean sandstones are interpreted as backstepping shoreface sandstones deposited on a marine transgressive surface of erosion during a transgression (MTSE; Fig. 5).

The occurrence of Carboniferous spores and pollen suggests that Carboniferous sediments may have been 
Heno Plateau

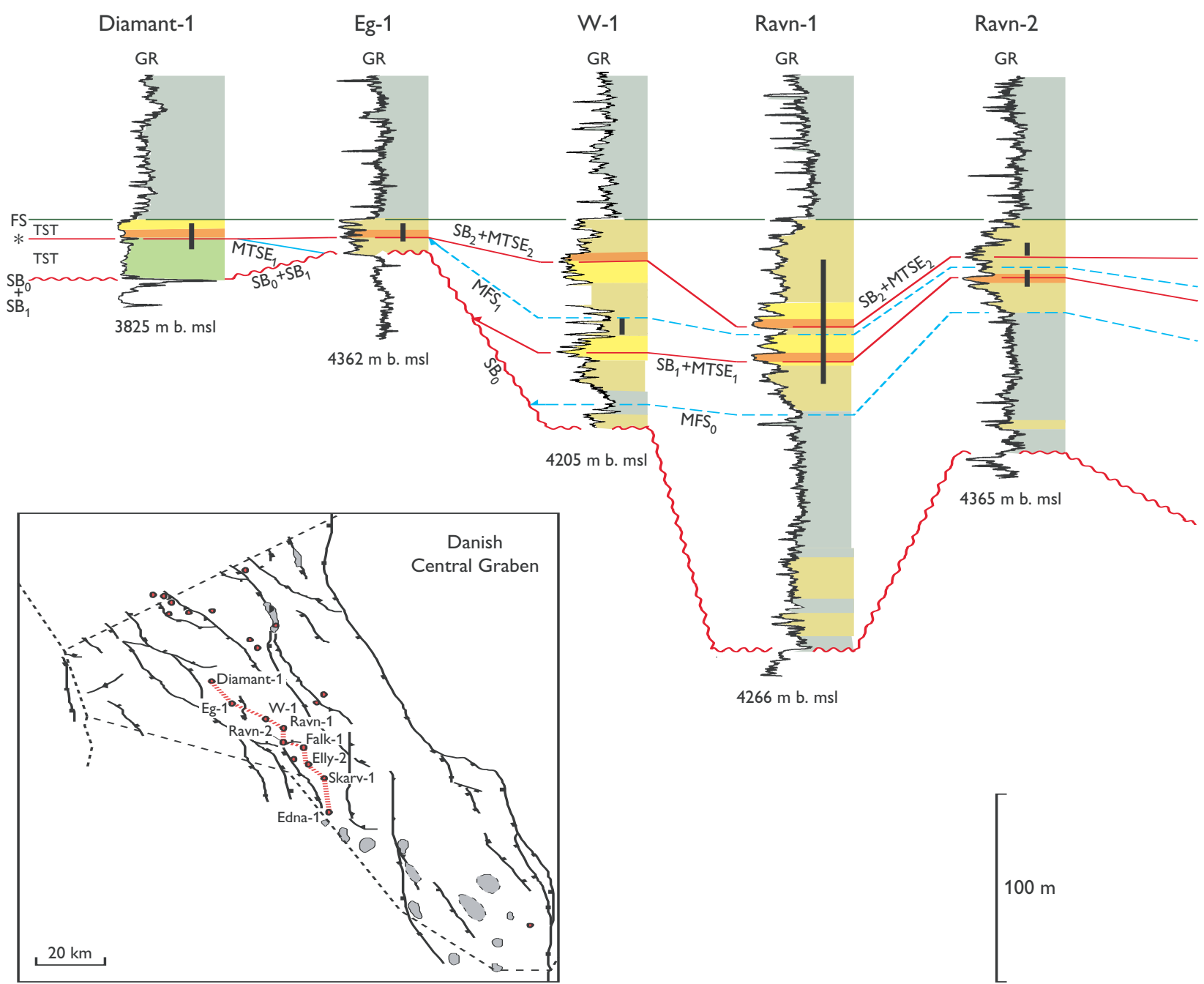

Fig. 8. Gamma-ray log panel of the Upper Jurassic sand-rich succession from the Heno Plateau to the Salt Dome Province in the northern part of the Danish Central Graben; for legend, see Fig. 5. The Falk-1, Elly-2 and Skarv-1 wells are located on the deeper, south-eastern part of the Heno Plateau. Note that the flooding surface used as the datum represents the upper limit of detailed investigation in this study; Andsbjerg \& Dybkjær (2003, this volume) interpret this surface as a composite flooding surface and sequence boundary in the Falk-1, Ravn-1 and Ravn-2 wells. Surface indicated with an asterisk is composite: $\mathrm{MTSE}_{1}+\mathrm{SB}_{2}+\mathrm{MTSE}_{2}$.

the dominant sediment source. Thick Carboniferous sandstones were cored below the Upper Jurassic sandstones in the nearby Gert-2 well, situated on the upthrown side of the fault between Gert-1 and Gert-2, and may represent a local source of sandy sediment.

\section{Further occurrences}

Transgressive back-barrier deposits overlain by shoreface sandstones also occur in the lowermost part of the Upper
Jurassic in the Gert-2, Jeppe-1, Karl-1, 2/12-1, Gert-4 and Diamant-1 wells (Figs 5, 8; Söderström et al. 1991; Johannessen \& Andsbjerg 1993; Johannessen 1995; Johannessen et al. 1996). The shoreface sandstones fine upwards in a stepwise manner to offshore claystones, suggesting continued transgression. On the Gertrud Plateau, the shoreface sandstones fine upwards into clayey sandstones deposited in a lower shoreface environment. The shoreface sandstones of Diamant- 1 on the westernmost part of the Heno Plateau are abruptly overlain by offshore claystones of the Farsund Formation 


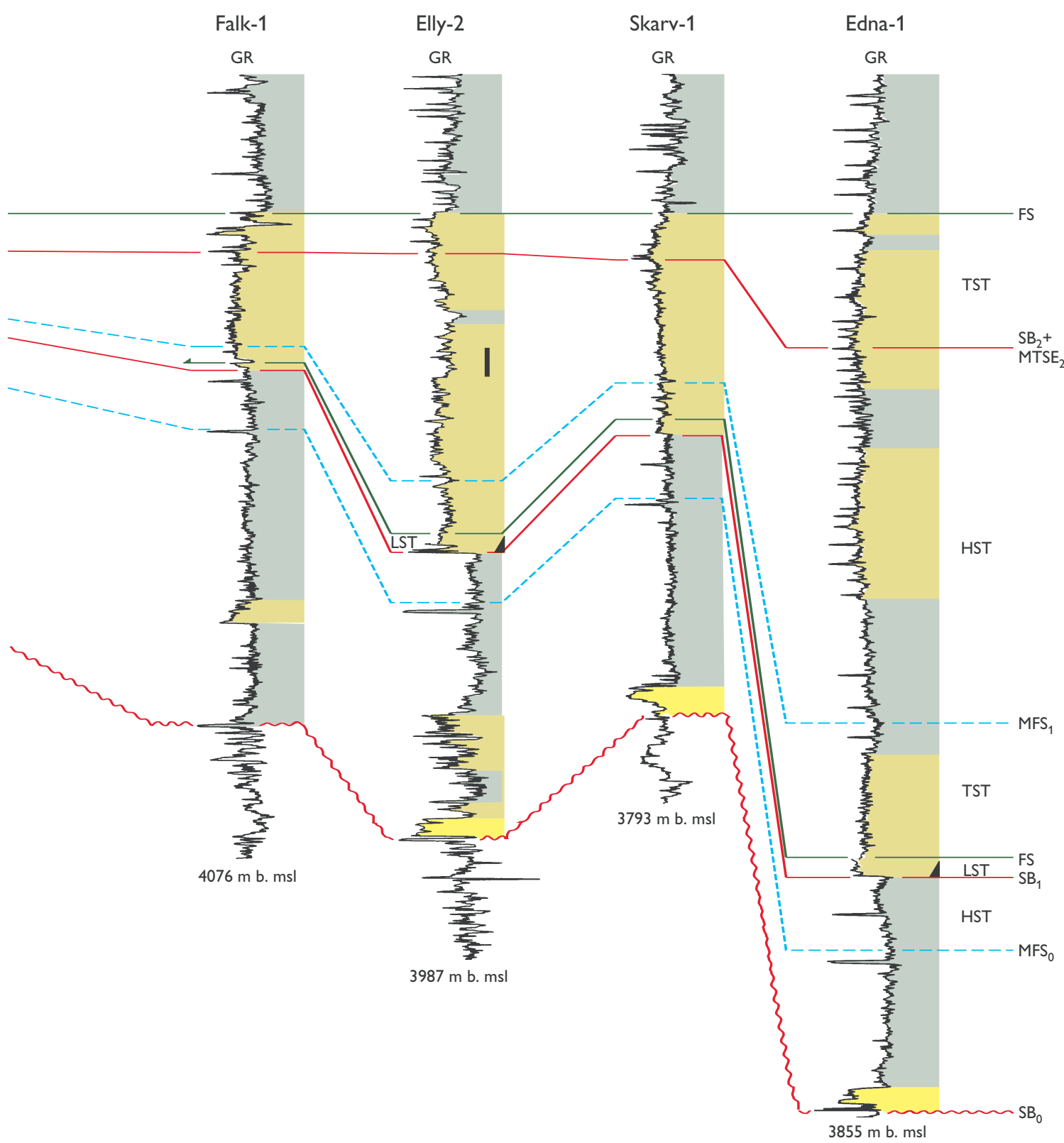

(Fig. 8). Offshore claystones of the Lola Formation (Fig. 8) were either never deposited in this area or were eroded during a subsequent fall in relative sea level. Back-barrier sediments overlain by transgressive shoreface sandstones are not recorded on the remaining part of the Heno Plateau, the southern part of the Gertrud Plateau nor in the Salt Dome Province and the Tail End Graben.

\section{Regressive-transgressive shoreface sandstones and conglomerates}

\section{Description}

Upper Jurassic sandstones form a unit up to $70 \mathrm{~m}$ thick on the Gertrud Plateau, partly cored in the Gert-2, Jeppe-1 and Gwen-2 wells (Figs 5, 9, 10). The sandstones are very fine- to medium-grained and form a coarsening-upwards succession; in the Gwen-2 and Jeppe- 1 wells, this is abruptly overlain by a conglom- 


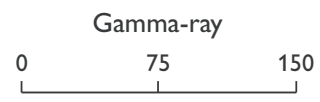

Gwen-2
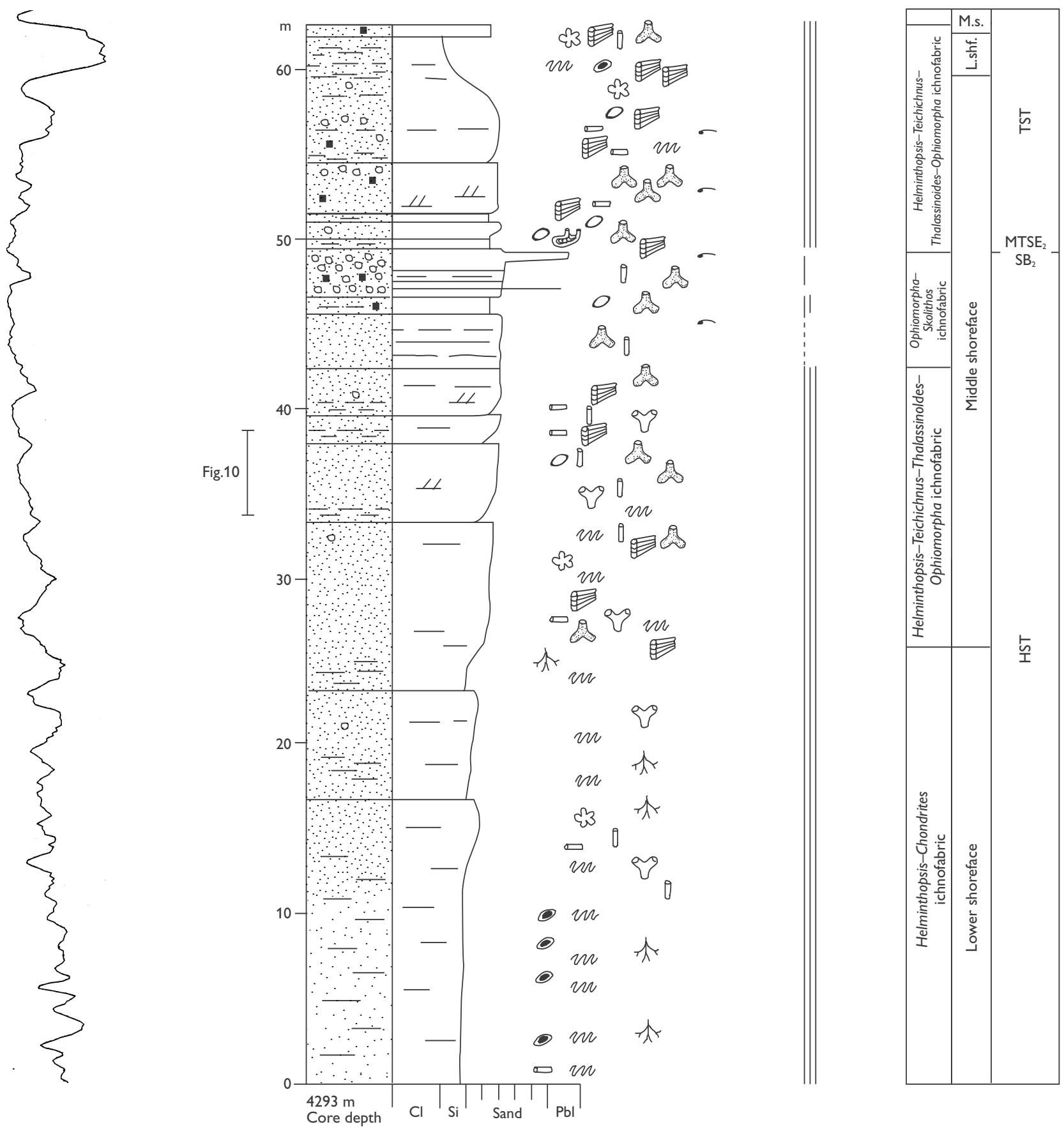

Fig. 9. Sedimentological core log of lower to middle shoreface sandstones from sequence 1 and the lower part of sequence 2 in the Gwen-2 well on the Gertrud Plateau. The sandstones display several coarsening-upwards parasequences. For legend, see Fig. 6. L.shf., lower shoreface; M.s., middle shoreface.

erate unit, $0.5-3 \mathrm{~m}$ thick (Figs 5,9). The upper part of the sandstone succession, comprising medium- to finegrained sandstones, fines upwards over an interval of 15-30 m (Fig. 5).

The organic matter consists primarily of brown and black wood. The relative abundances of dinoflagellate cysts are very high, forming up to $77 \%$ of the total palynomorph assemblage, compared to $0-3 \%$ in the back-barrier sediments in Gert-1 and Gert-2 (Johannessen et al. 1996).

The coarsening-upwards to fining-upwards sandstones are intensely bioturbated, often to such a degree that primary sedimentary structures are obliterated. Only 


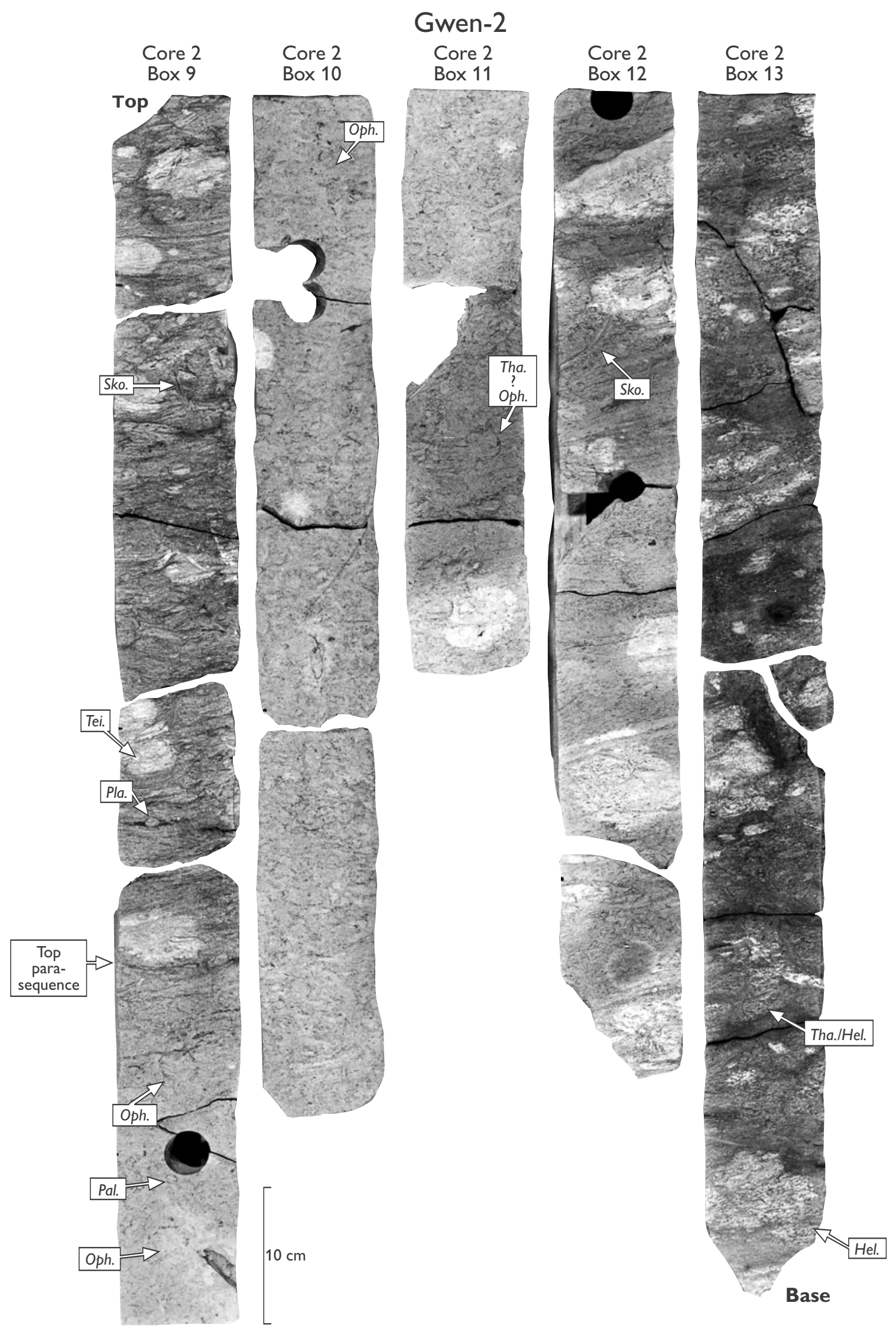

Fig. 10. Middle shoreface parasequence in sequence 1 in the Gwen-2 well. Note the vertical succession of trace fossils within the parasequence: Helminthopsis isp. (Hel.) and Thalassinoides isp. (Tha.) in the lower levels and Ophiomorpha isp. (Oph.) in the upper part. For position of core photos, see Fig. 9; for legend, see Fig. 7. Additional trace fossils: Pal., Palaeophycus heberti; Pla., Planolites isp.; Sko., Skolithos isp.; Tei., Teichichnus isp.; Tha./Hel., Thalassinoides isp. burrow reworked by Helminthopsis isp. 


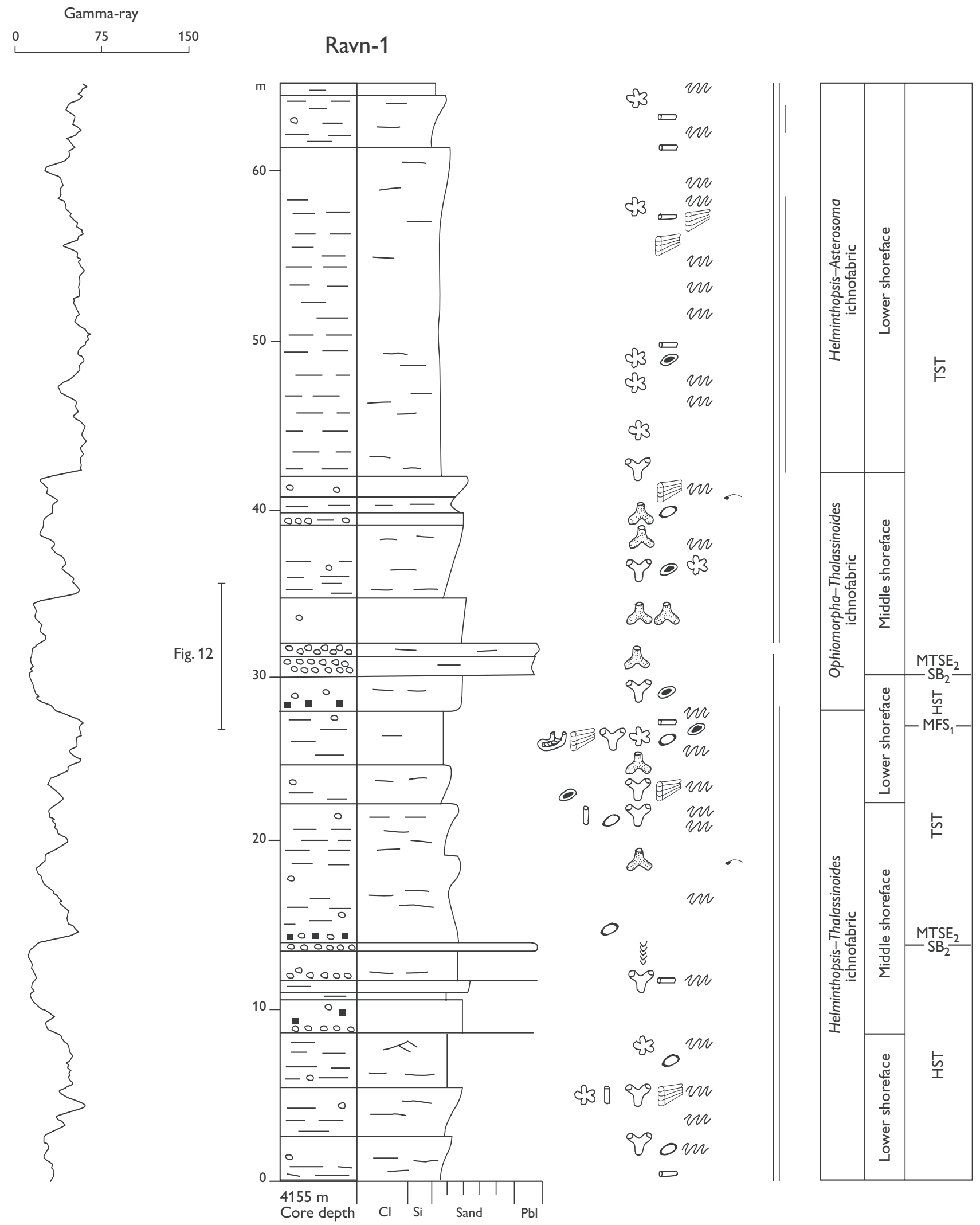

Fig. 11. Sedimentological core log of lower to middle shoreface sandstones from the upper part of sequence 0 , sequence 1 and the lower part of sequence 2 in the Ravn-1 well, located on the Heno Plateau. The sandstones are represented by several coarseningupwards parasequences. For legend, see Fig. 6. 
a few poorly-preserved cross-laminations are seen (Figs 9, 11). A vertical suite of ichnofabrics characterises the sandstones. The Helminthopsis-Chondrites ichnofabric is typical of the lowermost sandy siltstones of the cored section in Gwen-2 (Fig. 9). The Helminthopsis-Teichichnus-Thalassinoides-Ophiomorpha ichnofabric occurs higher up in the succession in very fine-grained sandstones. The Ophiomorpha-Skolithos ichnofabric characterises the two parallel-laminated, medium-grained sandstones, 3 and $2 \mathrm{~m}$ thick, in the uppermost part of the coarsening-upwards succession, immediately below the conglomerate of Gwen-2. The sandstone succession above the conglomerate is characterised by the Helminthopsis-Teichichnus-Thalassinoides-Ophiomorpha ichnofabric.

The overall coarsening-upwards and fining-upwards sandstone succession of the Heno Formation may itself be constructed of several smaller-scale coarseningupwards ('cleaning-upwards') units, $1.5-10 \mathrm{~m}$ thick (Figs 9, 10). Such small-scale rhythmic units may also show a characteristic vertical succession of ichnofabrics. A coarsening-upwards unit ( $4.75 \mathrm{~m}$ thick) of very fine- to fine-grained sandstones in the Gwen-2 well is illustrated here as an example (Fig. 10). Helminthopsis isp. dominates at the base, followed upwards by Thalassinoides isp. which is partly reworked by Helminthopsis isp. The middle part of the unit is characterised by Skolithos isp. and Thalassinoides isp. (Fig. 10). The upper, most coarse-grained part of the unit is dominated by many Ophiomorpha isp. burrows and a few Palaeophycus isp. traces. Immediately above the top of the unit, clay-rich very fine-grained sandstones are characterised by Planolites isp. and Teichichnus isp. and form the base of the next coarsening-upwards, "cleaningupwards' unit.

Out-sized quartz clasts, $0.5-3 \mathrm{~mm}$ in diameter, wellrounded and spherical, occur scattered within the bioturbated sandstones (Fig. 9). The conglomerates are mostly matrix-supported, but a few $2-4$ cm thick clastsupported conglomerate beds occur in Jeppe- 1 and Gwen-2. The clasts are $0.5-2 \mathrm{~cm}$ in diameter, and the matrix consists of fine- to medium-grained sandstone with pyrite, coal fragments and bivalve shells.

\section{Interpretation}

The high diversity and high density trace fossil assemblage and the high relative abundance of marine palynomorphs, together with the land-derived organic matter, indicate that the sandstones and conglomerates were deposited on a marine shoreface with normal salinities and a strong terrestrial influence.

The Helminthopsis-Chondrites ichnofabric is the result of deposit-feeding animals and indicates poor oxygen conditions (Bromley 1990). The diverse trace fossil assemblage of the Helminthopsis-TeichichnusThalassinoides-Ophiomorpha ichnofabric was created by organisms that required more oxic conditions, indicating that the oxygen level at the sea bottom had increased (Bromley 1990). Thalassinoides and Ophiomorpha traces represent permanent dwelling burrows, indicating that the energy conditions were higher such that the organisms constructed protective domiciles. The ichnofabrics of the lower and middle part of the coarsening-upwards succession represent the Cruziana ichnofacies (Seilacher 1967). The two parallel-laminated sandstone beds immediately below the conglomerate in Gwen-2 (Fig. 9) are characterised by a few Ophiomorpha isp. and Skolithos isp. burrows. This ichnofabric consists only of permanent dwelling burrows and high depositional energy is also indicated by the parallel lamination. The burrows represent dwelling structures and/or the activity of suspension-feeding animals and are typical of the Skolithos ichnofacies (Seilacher 1967). Sedimentation rates were either sufficiently high or the degree of bioturbation was reduced, allowing preservation of the lamination. The sandstones were probably deposited in upper flow regime conditions during storms.

The Cruziana ichnofacies characterises sediments deposited between fair-weather wave base and storm wave base, within the lower shoreface (Frey \& Pemberton 1985). The Skolithos ichnofacies is characteristic of well-sorted sands deposited under high-energy conditions with frequent erosion and reworking, conditions typical of the middle to upper shoreface (Pemberton et al. 1992).

The few preserved cross-laminations indicate that traction currents operated over the sea floor giving rise to migrating small-scale ripples. The bioturbated sandstones characterising the bulk of the Heno Formation are interpreted as having been deposited by storm-generated currents that transported sand from the beach to the middle and lower shoreface. The scattered outsized matrix-supported quartz clasts were possibly deposited on scour surfaces by storm currents that swept across the sea floor; the clasts were subsequently dispersed in the sediment by burrowing. Open burrows filled with shell debris and large clasts transported by storm-generated currents, as reported from comparable facies in the Fulmar Formation (Taylor \& 
Gawthorpe 1993), have not been recognised in the shoreface sandstones of the Heno Formation. The fact that the shoreface sandstones of the Heno Formation are completely bioturbated suggests that each storm sand bed was relatively thin and/or that the mid-tier and shallow-tier trace fossils were able to completely penetrate the storm sand beds.

The coarsening-upwards succession represents progradation of a lower to middle shoreface sandstone wedge, while the succeeding fining-upwards succession represents the subsequent backstepping of middle to lower shoreface sandstone wedges. The small-scale coarsening-upwards units, 1.5-10 m thick in Gwen-2 (Fig. 9), possibly represent minor shoreface progradational events. The coarsening-upwards unit illustrated from the Gwen-2 well (Fig. 10), shows ichnofabrics of the Cruziana ichnofacies at the base, suggesting moderate energy conditions, and the Skolithos ichnofacies at the top, suggesting high-energy conditions (Seilacher 1967). The very fine-grained, clayey sandstones that abruptly overlie the coarsening-upwards unit and are dominated by Planolites and Teichichnus traces produced by deposit feeders, indicate a dramatic change to much lower energy conditions (Fig. 10).

In general, the vertical successions of ichnofabrics in the Heno Formation are closely comparable to those described by Taylor \& Gawthorpe (1993) from the Upper Kimmeridgian - Lower Volgian shoreface sandstones of the Ula Formation of the southern Norwegian Central Graben. In contrast, however, neither the Siphonichnus ichnofabric nor the Glossifungites ichnofacies, which have been described from the Ula and Fulmar Formations (Taylor \& Gawthorpe 1993), were recognised in the Heno Formation.

The conglomerates that abruptly overlie the coarsening-upwards shoreface sandstones and are overlain by fining-upwards middle shoreface sandstones are interpreted as lags formed during transgression upon a marine transgressive surface of erosion, $\mathrm{MTSE}_{2}$ (Fig. 9). The clasts of the conglomerates are much larger than the out-sized clasts in the shoreface sandstones. The conglomerates are therefore interpreted to represent storm events on the beach/shoreface or reworked fluvial deposits formed during maximum regression. Shoreface erosion during the subsequent transgression is thought to have obliterated evidence of individual coarse-grained storm beds and evidence of subaerial exposure. The large number of coal clasts within the conglomerates, however, may indicate fluvial erosion of peat deposits. The backstepping upper part of the shoreface sandstone succession is abruptly overlain by offshore clay- stones of the Farsund Formation, a feature also seen in the Fulmar Formation and, to some degree, in the Ula Formation (Howell et al. 1996).

\section{Further occurrences}

Regressive to transgressive shoreface sandstones and conglomerates occur in all the wells on the Heno and Gertrud Plateaus with the exception of Diamant-1 where only transgressive sandstones occur and Gert-2 where conglomerates are missing (Fig. 8).

The section in the Ravn-1 well, in the southern part of the Heno Plateau (Figs 1, 4, 5, 8), includes two pebble conglomerate beds in the more than $100 \mathrm{~m}$ thick fine-grained sandstone succession of the Heno Formation (Fig. 11). The lower conglomerate is $0.25 \mathrm{~m}$ thick, with clast sizes of up to $3 \mathrm{~cm}$ in diameter; no imbrication of clasts is seen. The upper conglomerate is $c .2 \mathrm{~m}$ thick and varies from clast- to matrix-supported, with clast sizes of $0.3-1 \mathrm{~cm}$ (Fig. 12); it overlies fine- to mediumgrained sandstones characterised by an OphiomorphaThalassinoides ichnofabric (Fig. 11). An overall finingupwards succession characterises the section above both of the conglomerate units in Ravn-1 (Figs 8, 11).

Regressive-transgressive shoreface sandstones without conglomerates are present in all wells in the Feda Graben and the Salt Dome Province adjacent to the plateau areas and on the deeper, south-eastern part of the Heno Plateau (Figs 5, 8, 13). The grain size becomes finer as the distance to the plateau areas increases, suggesting that shoreface sandstones are only represented close to the margins of the grabens. The sandstones show a gradual fining-upwards and grade up into offshore claystones of the Farsund Formation. The lower shoreface sandstones in the Salt Dome Province, on the south-east Heno Plateau and the southern part of the Gertrud Plateau are described below. Shoreface sandstones are not observed in the Tail End Graben (Fig. 13).

\section{Sharp-based lower shoreface sandstones}

\section{Description}

In the Elly-2 well, in the deeper, south-eastern part of the Heno Plateau, very fine-grained clayey sandstones form a succession $185 \mathrm{~m}$ thick characterised by relatively low gamma-ray values (Figs 1, 4, 8). The sandstones abruptly overlie claystones with high gamma-ray values, and are overlain by similar claystones. The sand- 

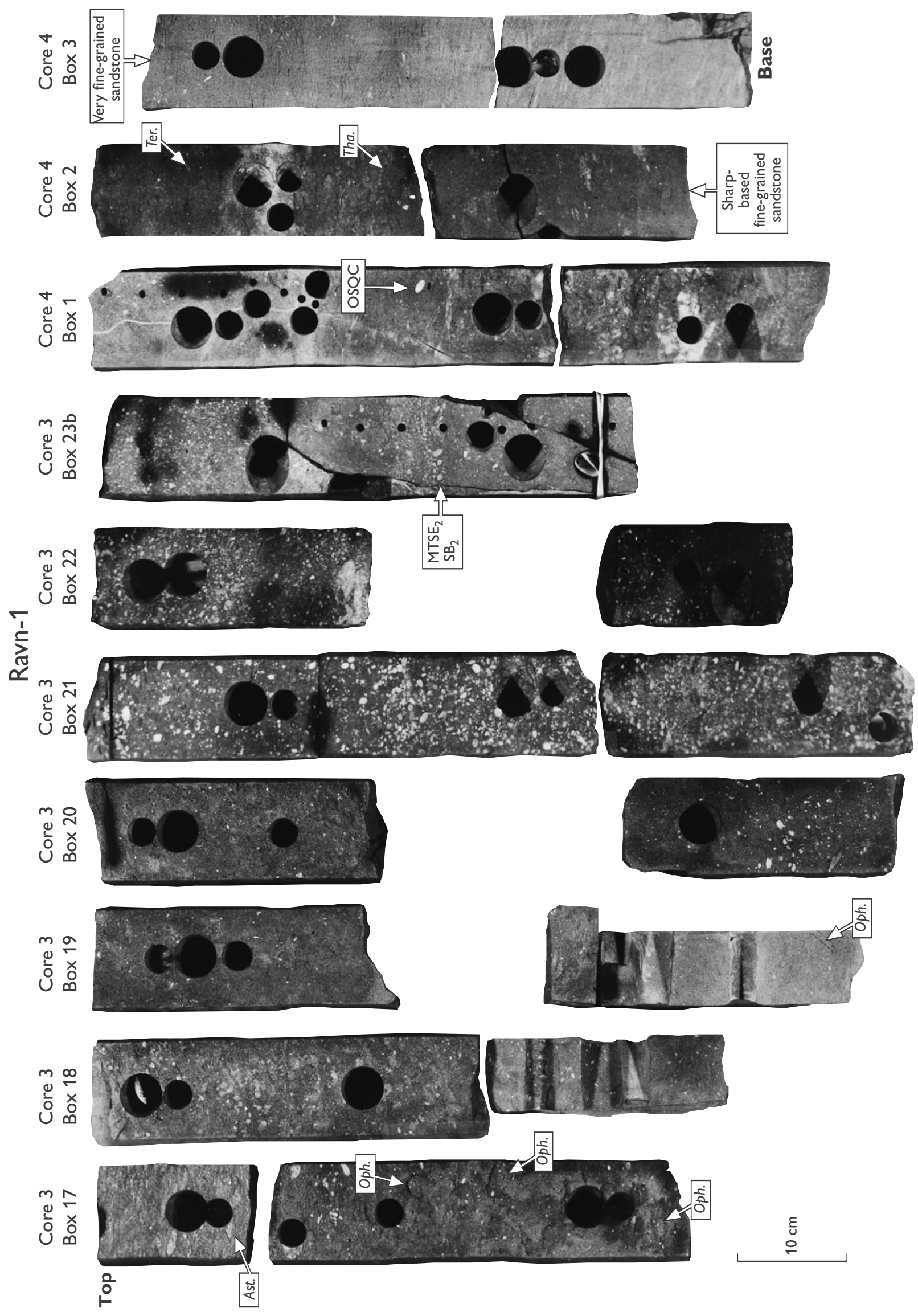
stones and the claystones contain abundant dinoflagellates. Two units (0.5-1 m thick) in the claystones immediately below the sandstones show low gammaray and sonic readings and high resistivity readings and form discrete log markers; cuttings samples suggest that these units consist of carbonate-cemented sediment. These log markers are also recognised in the Elly-2, Falk-1, Skarv-1 and Edna-1 wells on the south-eastern Heno Plateau and in the Salt Dome Province (Fig. 8). The sandstones sharply overlie the uppermost calcareous marker bed in Elly-2 whereas in the other wells, the uppermost calcareous bed is situated $10-25 \mathrm{~m}$ below the sharp-based, very fine-grained clayey sandstones.

A $50 \mathrm{~m}$ thick unit in the middle part of the sandstone succession in Elly-2 shows slightly higher gamma-ray readings, indicating that it is more clay-rich than the sandstones above and below (Fig. 8). A core (20 m thick) in the lowermost part of this section (Fig. 8) comprises very fine-grained, glauconitic sandstones and sandy siltstones, which are heavily bioturbated with a high diversity trace fossil assemblage. In the lower to middle part of the core, mostly comprising sandy siltstones, the ichnofauna consists only of Helminthopsis isp. In the more sandy intervals, the diversity of trace fossils is much higher with burrows of Asterosoma isp., Chondrites isp., Helminthopsis horizontalis, Ophiomorpha isp., Palaeophycus isp., Planolites isp., Rhizocorallium isp., Skolithos isp., Teichichnus isp., Terebellina isp. and Thalassinoides isp., defining the Cruziana ichnofacies (Seilacher 1967). In the upper half of the core, several very fine-grained sandstone beds, $8-10 \mathrm{~cm}$ thick, are interbedded with clayey to silty, very fine-grained sandstones. No primary sedimentary structures are preserved in the sandstones, presumably due to the intensive bioturbation. Bed boundaries are also thoroughly bioturbated.

\section{Interpretation}

The high diversity trace fossil assemblage and the large number of dinoflagellate cysts indicate that the finegrained sandstones were deposited under well-oxygenated conditions in a fully marine environment, probably the lower shoreface. The sandy siltstones with an ichnofabric consisting solely of Helminthopsis isp. were probably deposited under poorly oxygenated conditions (Bromley 1990; Johannessen 1995). The very fine-grained sandstones, interbedded with clayey to silty, very fine-grained sandstones in the upper part of the Elly-2 section, were probably deposited from stormgenerated currents. Formation of glauconite takes place below wave base (Odin \& Fullagar 1988; Hansley \& Whitney 1990). From their studies of the Upper Cretaceous Shannon Sandstone (USA), Walker \& Bergman (1993) suggested that glauconite sands originally formed below wave base but were subsequently reworked during a forced regression into wave-dominated shoreface sandstones. The abnormally high gamma-ray values in the lower shoreface sandstones are due to the large content of glauconite which contains radioactive potassium.

The sharp-based sandstones overlying the offshore claystones in Elly-2 indicate a sudden increase in depositional energy. The uppermost calcareous marker bed is situated immediately below the sharp-based sandstone, in contrast to the other wells in the south-east of the Heno Plateau and the Salt Dome Province where the calcareous marker occurs some 10-25 m below the sharp-based sandstones. It is considered likely therefore that up to $25 \mathrm{~m}$ of offshore claystones were stripped away prior to deposition of the sandstones in the Elly-2 area. Comparable shoreface sandstones resting on a sharp, erosional surface have been described by Plint (1988) from the Cardium Formation in Canada.

\section{Further occurrences}

Sharp-based, clayey, very fine-grained lower shoreface sandstones are also recognised in the Falk-1, Skarv-1 and Edna-1 wells situated on the south-east Heno Plateau and in the Salt Dome Province, and also in the Gwen-2 and Q-1 wells, on the southernmost part of the Gertrud Plateau (Fig. 8). The sandstones of these wells are finergrained than the sandstones in Elly-2, based on cuttings samples and petrophysical logs. A casing shoe was placed at the bottom of the sharp-based sandstones in the Elly-2 and Edna-1 wells, such that the abrupt nature of the boundary may be in part an artefact. Similar sandstones occur, however, in the Falk-1 and Skarv-1 wells where no casing shoe disturbs this boundary (Fig. 8); the sharp-based sandstones observed in these wells are also interpreted to have been deposited on an erosional surface. Sharp-based shoreface sandstones have not been recorded from the Tail End Graben (Fig. 13).

\section{Depositional sequences and basin development}

High resolution sequence stratigraphic interpretation of deposits in an active rift basin such as the Central 
Graben can be problematic for a number of reasons. Subsidence rates in different parts of the basin may vary strongly. Local sand sources may be shut off almost instantaneously due to drowning as a result of relative sea-level rise (Johannessen et al. 1996). Footwall uplift may create new sediment source areas whilst subsidence of hanging-walls can create increased accommodation space resulting in thick prograding shoreface wedges (Gawthorpe et al. 1994; Johannessen et al. 1996). Furthermore, small rotating half-grabens near the main sediment sources may trap sediment before reaching the deeper part of the basin.

The Kimmeridgian sandstone succession of the Danish Central Graben is subdivided into two sequences (sequences 1 and 2 ) that are described below. The underlying sequence (sequence 0 ) is largely outside the scope of this study but is also described briefly below. Sequences 0,1 and 2 of this study are equivalent to the Kimm-1, Kimm-2 and Kimm-3 sequences, respectively, in the regional Jurassic sequence stratigraphic study by Andsbjerg \& Dybkjær (2003, this volume).

\section{Sequence 0}

As noted above, sequence 0, beneath the Heno Formation sandstones, is outside the scope of the study but the upper levels are discussed here to provide the stratigraphic context of the succeeding sand-rich sequences; for further details of this sequence, the reader is referred to Andsbjerg \& Dybkjær (2003, this volume) where sequence 0 of this study corresponds to their Kimm-1 sequence. The upper part of sequence 0 consists of a highstand systems tract overlying a maximum flooding surface $\left(\mathrm{MFS}_{0}\right)$; it is present on the south-eastern part of the Gertrud Plateau, the south-eastern part of the Heno Plateau and in the Tail End Graben (Figs 5, 8, 13).

\section{Highstand systems tract}

The coarsening-upwards succession above the Lola Formation offshore claystones, which span the $\mathrm{MFS}_{0}$ (Figs $14 \mathrm{~A}, 15)$, is interpreted as a progradational shoreface wedge and is referred to the highstand systems tract (Figs $5,8,13)$. The most coarse-grained shoreface sandstones occur in the W-1, Ravn-1 and Ravn-2 wells on the southern part of the Heno Plateau (Figs 5, 8). In Ravn-1, three well-defined parasequences form a forestepping parasequence set.

In the Gwen-2 and Q-1 wells, on the southern part of the Gertrud Plateau, the highstand systems tract consists of weakly coarsening-upwards offshore claystones (Fig. 5). A succession of offshore claystones grading up
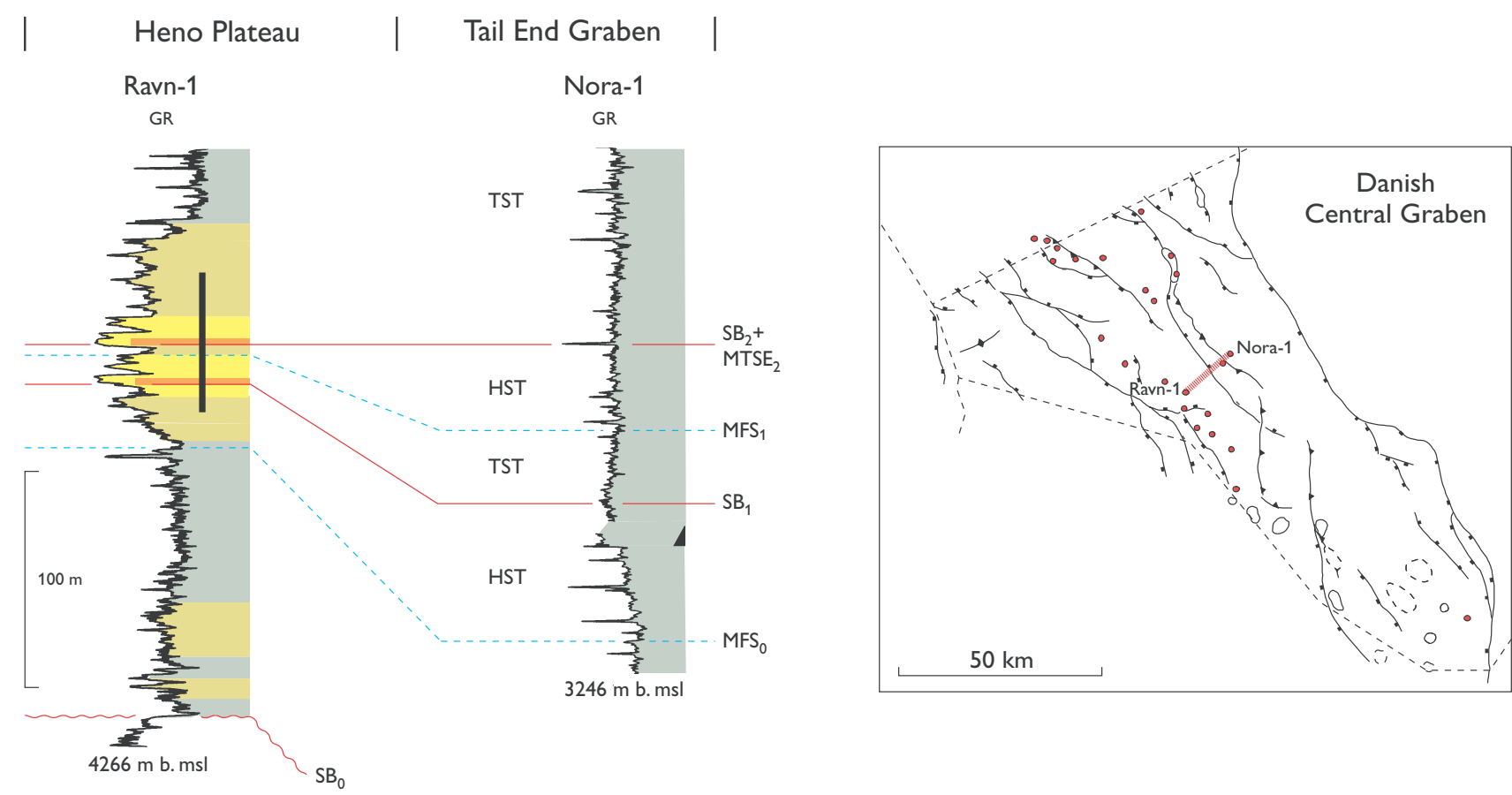

Fig. 13. Gamma-ray log correlation from the easternmost part of the Heno Plateau (Ravn-1) out into the Tail End Graben (Nora-1), adjacent to the Heno Plateau. Sharp-based shoreface sandstones are not observed in the Tail End Graben. Sequence stratigraphic boundaries in the Nora-1 well are from Andsbjerg \& Dybkjær (2003, this volume). For legend, see Fig. 5. 

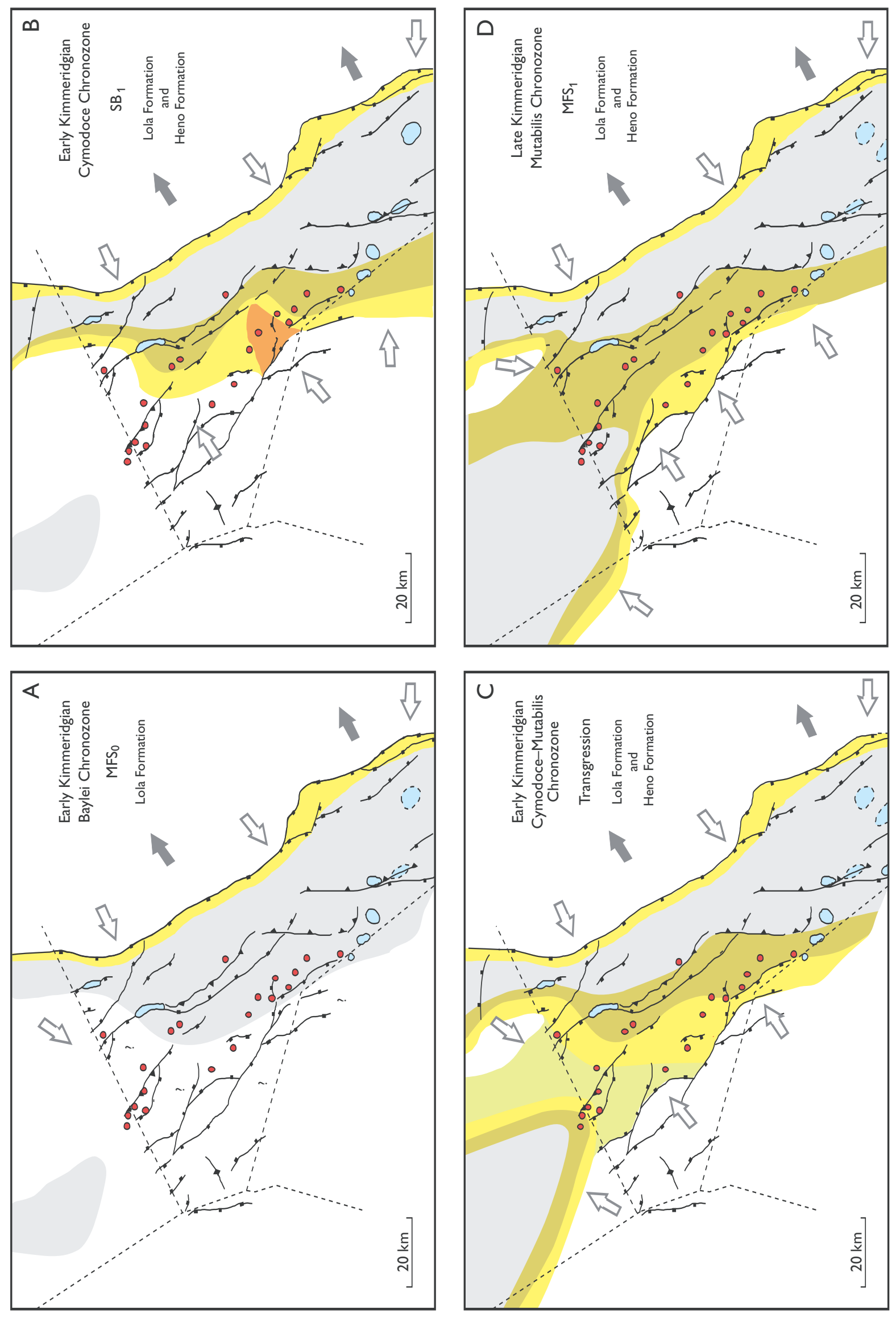

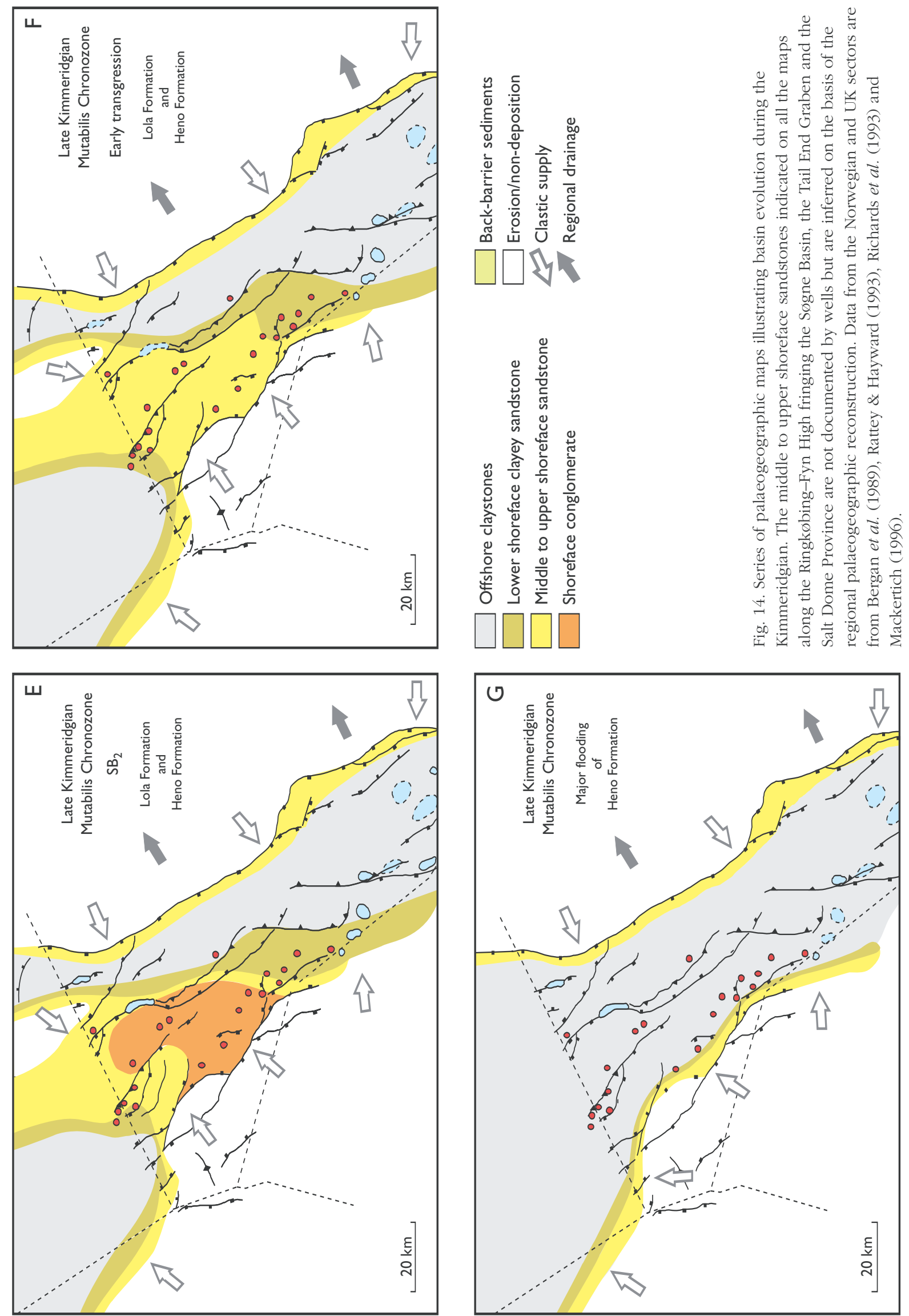

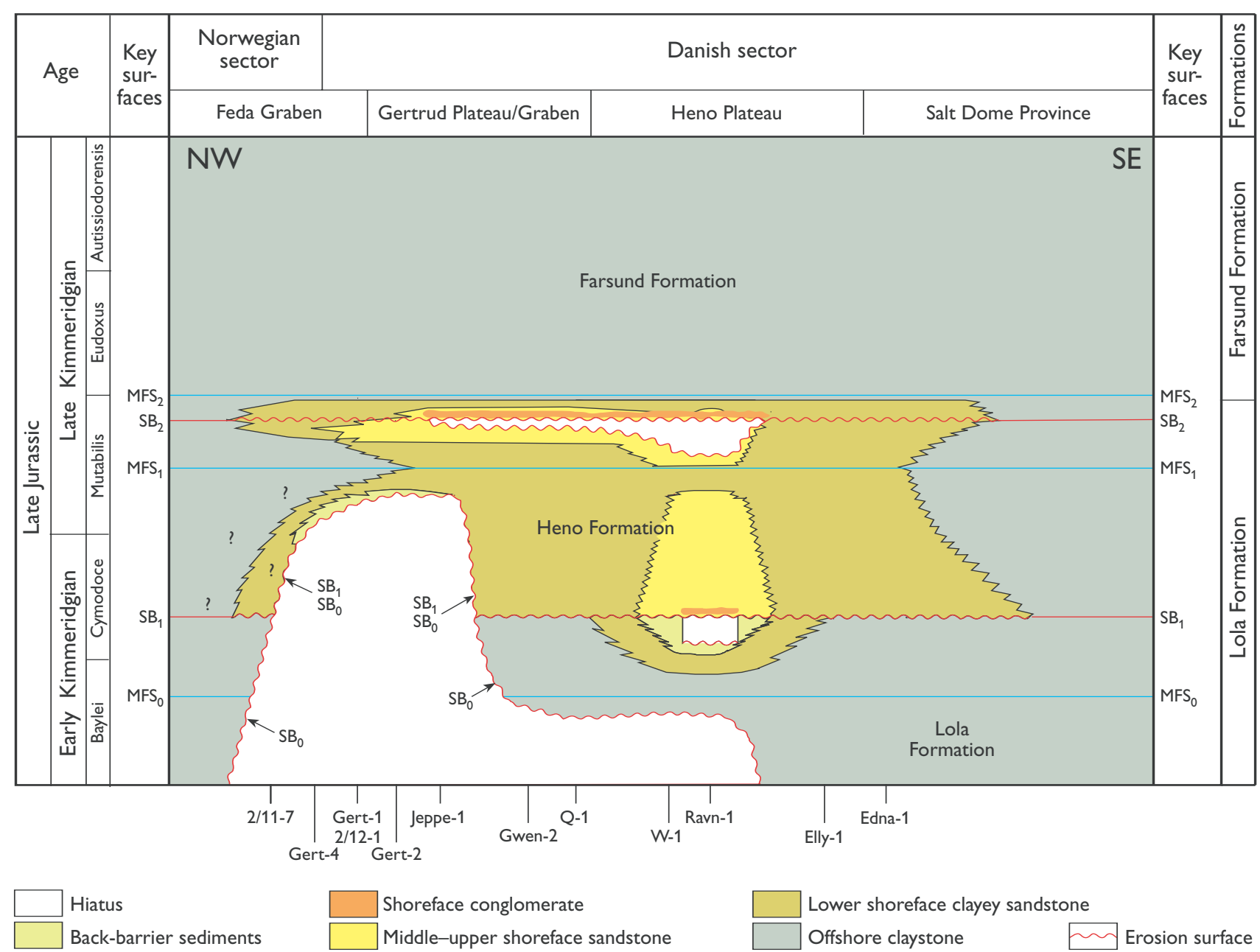

Lower shoreface clayey sandstone

Offshore claystone

Erosion surface

Fig. 15. Late Jurassic time stratigraphic correlation chart of the northern part of the Danish Central Graben and the southernmost part of the Norwegian Central Graben. The question-marks in the Norwegian part of the section indicate that lower shoreface sandstones and back-barrier sediments of Early Kimmeridgian age have not been documented to date, but are predicted on the basis of this study.

into siltstones occurs on the south-east Heno Plateau and in the Salt Dome Province (Falk-1, Elly-2; Figs 8, 13). In contrast, in the Skarv-1 well, a coarsening-upwards trend is not evident; the offshore claystones and siltstones are abruptly overlain by clayey, very fine-grained sandstones in this well (Fig. 8).

Sequence 0 is not recognised in the Feda Graben nor on the northern part of the Gertrud Plateau indicating either uplift and erosion or non-deposition due to the positive nature of these structures (Figs 14A, B, 15, 16A, $\mathrm{B})$. The shoreface sandstones prograded towards the east across the Heno Plateau and probably the easternmost Gertrud Plateau before pinching out in the westernmost Tail End Graben and Søgne Basin (Fig. 14B). Shoreface sandstones may also have been deposited along the easternmost flank of these basins, bordering the Ringkøbing-Fyn High.

\section{Sequence 1}

In the south-eastern part of the Gertrud Plateau and the Tail End Graben, sequence 1 consists of lowstand, transgressive and highstand systems tracts (Figs 8, 13). On the northern part of the Gertrud Plateau, the southern part of the Heno Plateau and in the Feda Graben, sequence 1 consists of transgressive and highstand systems tracts (Figs 8,13). On the western part of the Heno Plateau, sequence 1 consists only of sediments of the transgressive systems tract (Fig. 8). Sequence 1 
corresponds to the Kimm-2 sequence of Andsbjerg \& Dybkjær (2003, this volume).

Lower sequence boundary $\left(\mathrm{SB}_{1}\right)$ and the lowstand systems tract

The sequence boundary $\mathrm{SB}_{1}$ merges with the regional 'base Upper Jurassic' unconformity in the western part of the Heno Plateau, the northern part of the Gertrud Plateau and the Feda Graben (Figs 5, 8). This suggests that these areas experienced sediment bypass and that sediment was deposited farther out in the deeper parts of the basin (Figs 14B, 15, 16B, C).

The conglomerates in Ravn-1 and Ravn-2 were probably deposited during sea-level fall and subsequent sea-level rise and the base of the conglomerate unit is thus interpreted as a sequence boundary, $\mathrm{SB}_{1}$ (Figs 5, 8). In the W- 1 well, the $\mathrm{SB}_{1}$ is placed at the top of the regressive sandstones, i.e. at the maximum regression. The sharp-based sandstones of the southern part of the Gertrud Plateau (Q-1, Gwen-2) and the south-east Heno Plateau and Salt Dome Province (Falk-1, Elly-2, Skarv1, Edna-1) are situated on a regional erosional surface caused by a fall in sea level. The base of the sharp-based sandstones thus represents a sequence boundary $\left(\mathrm{SB}_{1}\right.$; Figs 5, 8).

Due to this inferred fall in sea level, the sharp-based sandstones extend farther out in the basin than the shoreface sandstones of the underlying highstand systems tract (Fig. 15). It is thought likely that comparable sharp-based sandstones were deposited in the Feda Graben, but well data are presently not available.

As the sharp-based sandstones shale out over short distances basinward, they probably represent the most distal part of a progradational wedge of shoreface sandstone. This suggests that they were deposited close to the time when relative sea level reached its lowest position; they are thus referred to the lowstand systems tract (Posamentier \& Vail 1988; Van Wagoner et al. 1990; Hunt \& Tucker 1992, 1995; Helland-Hansen \& Gjelberg 1994).

On the south-east Heno Plateau and in the Salt Dome Province, the lowstand systems tract consists of a package (5-10 $\mathrm{m}$ thick) of aggradational clayey, very finegrained, lower shoreface sandstones. On the south-eastern part of the Gertrud Plateau, the lowstand systems tract consists of lower shoreface siltstones, forming a unit 5-10 $\mathrm{m}$ thick (Figs 8,13 ). The top of the lowstand systems tract is defined at the base of a fining-upwards succession, which is referred to the succeeding transgressive systems tract (Figs 14B, 15, 16B).
Sharp-based shoreface sandstones are not seen in the Tail End Graben (Fig. 13).

\section{Transgressive systems tract and MFS,}

The transgressive systems tract is recognised in all the wells in the study area. The transition from the lowstand systems tract to the transgressive systems tract is similarly developed on the southern part of the Gertrud Plateau, on the south-east Heno Plateau and in the Salt Dome Province (Figs 8, 13). In the Gwen-2 well, a weakly fining-upwards succession of clayey siltstones, c. $40 \mathrm{~m}$ thick, deposited on a lower shoreface, shows a backstepping pattern capped by a maximum flooding surface (MFS ; Fig. 5).

In the Ravn-1 well on the Heno Plateau, the basal sequence boundary $\left(\mathrm{SB}_{1}\right)$ is overlain by a conglomerate, $0.25 \mathrm{~m}$ thick, followed by three backstepping parasequences, each 2-5 m thick, representing the transgressive systems tract (Figs 8, 13).

In the Feda Graben (2/12-1) and on the Gertrud Plateau (Gert-2; Fig. 5), the transgressive systems tract consists of a vertical succession of back-barrier sediments, shoreface sandstones and offshore claystones; the tract is c. $180 \mathrm{~m}$ and c. $25 \mathrm{~m}$ thick, respectively, in the 2/12-1 and Gert-2 wells (Johannessen et al. 1996). The transgressive systems tract in the Feda Graben and the northern part of the Gertrud Plateau overlies sequence boundary $\mathrm{SB}_{1}$, which here coincides with the 'base Upper Jurassic' unconformity (Fig. 5).

In the Diamant-1 well, near the Inge High on the westernmost part of the Heno Plateau, a succession of backbarrier sediments, $23 \mathrm{~m}$ thick, makes up part of the transgressive systems tract (Fig. 8). This succession overlies the sequence boundary $\mathrm{SB}_{1}$, coinciding with the 'base Upper Jurassic' unconformity (Fig. 8). The back-barrier sediments are erosionally overlain by a conglomerate, $2 \mathrm{~m}$ thick. The conglomerate in the Diamant- 1 well was probably deposited during a fall in relative sea level, related to the formation of $\mathrm{SB}_{2}$, and was later reworked during a rise in relative sea level associated with the formation of a marine transgressive surface of erosion (MTSE $E_{2}$ ). The base of the conglomerate thus represents the MTSE ${ }_{1}, \mathrm{SB}_{2}$ and $\mathrm{MTSE}_{2}$ merged together, defining the top of the transgressive systems tract (Fig. 8).

In the Eg-1 well, the transgressive systems tract consists of a fining-upwards succession (10 m thick) of very fine-grained lower shoreface sandstones (Fig. 8). A thin conglomerate, $8 \mathrm{~cm}$ thick, abruptly overlying the shoreface sandstones, defines the upper sequence 

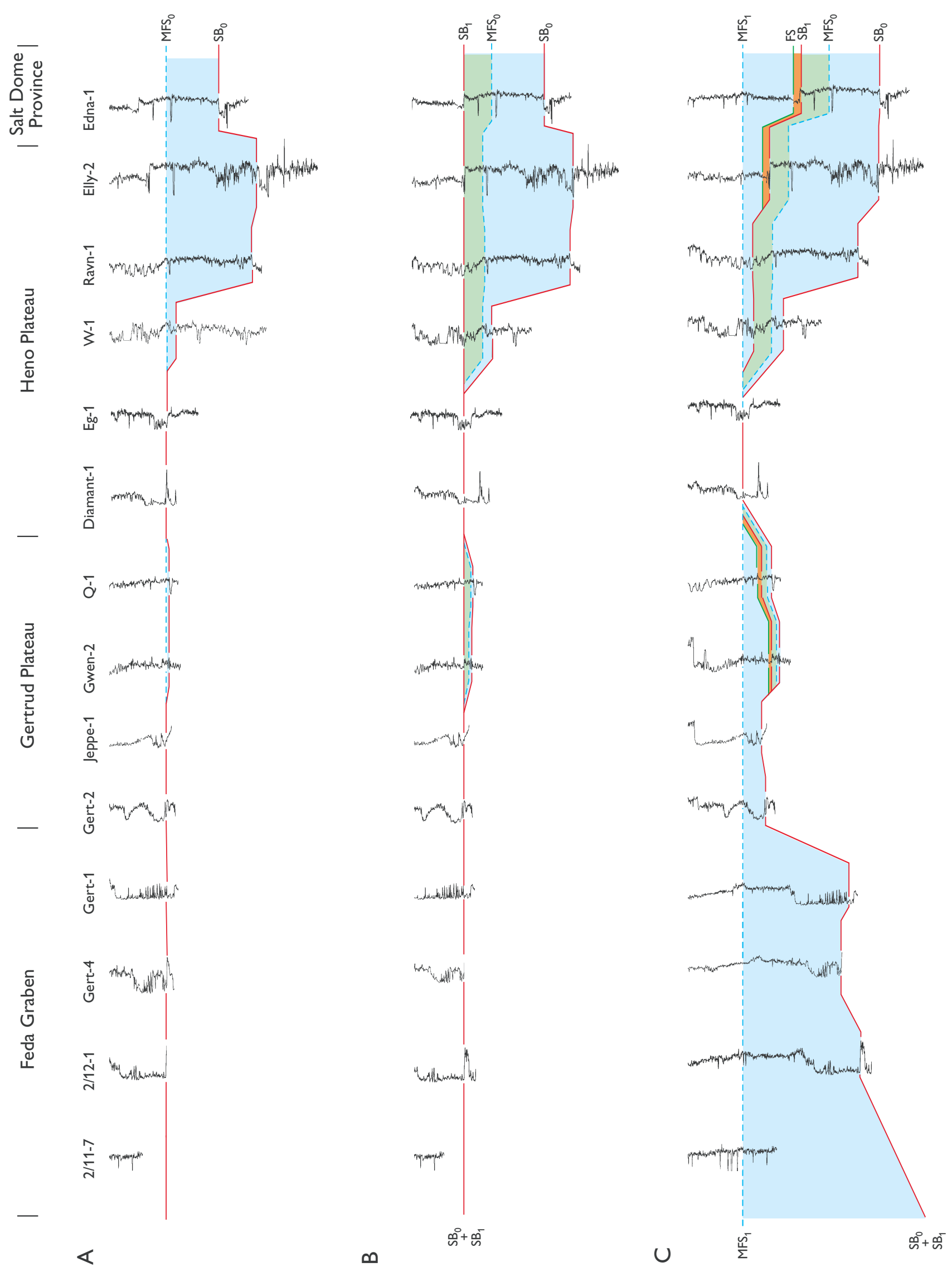


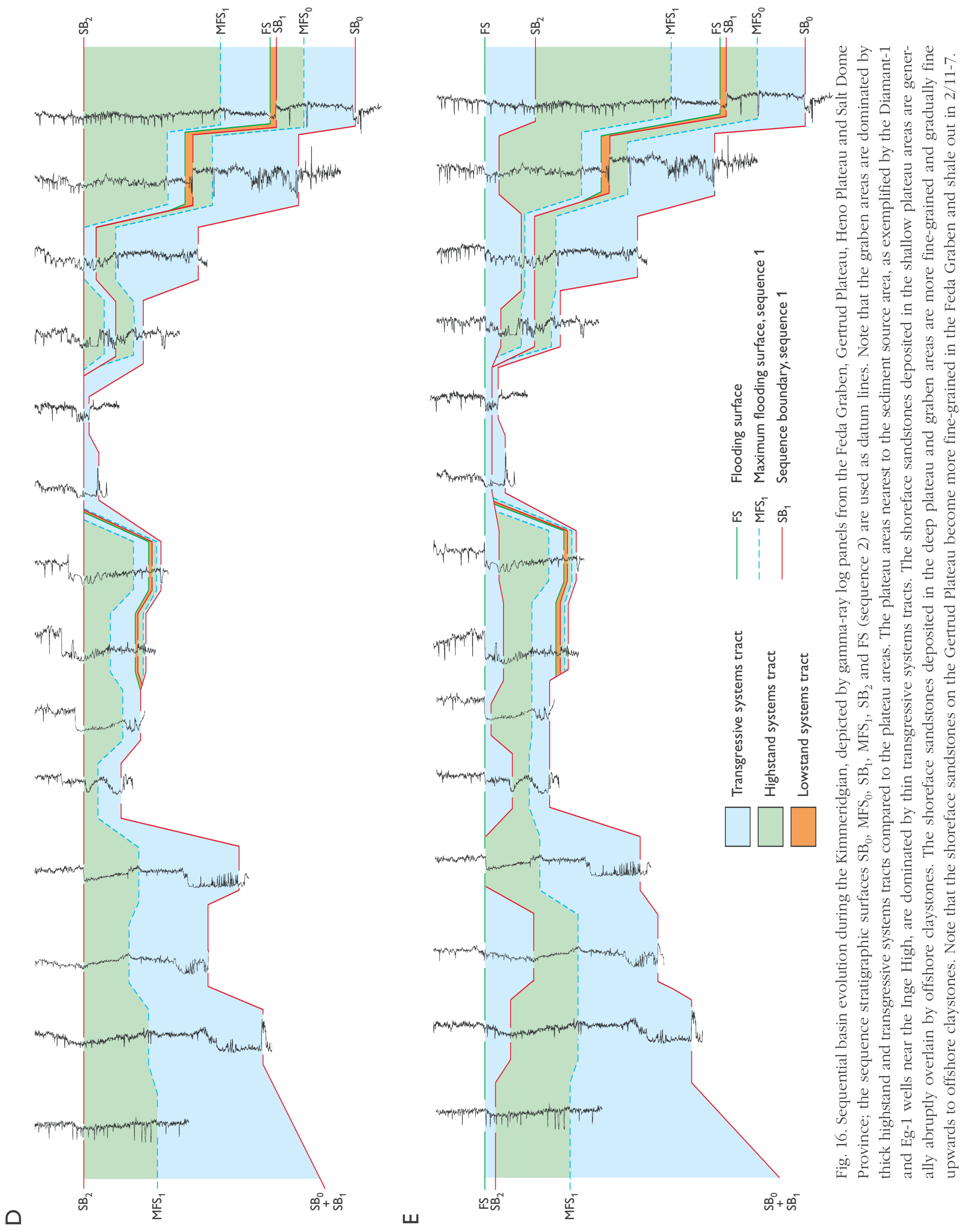


boundary $\left(\mathrm{SB}_{2}\right)$; middle shoreface sandstones were probably eroded during the fall in sea level that created this sequence boundary. A marine transgressive surface of erosion, $\mathrm{MTSE}_{1}$, is inferred to separate transgressive back-barrier sediments in Diamant-1 from the transgressive shoreface sandstones observed in Eg-1 (Fig. 8). The Heno and Gertrud Plateaus were transgressed both from the east and the west (Figs 14B-D, 15, 16B, C).

\section{Highstand systems tract and the} upper sequence boundary $\left(\mathrm{SB}_{2}\right)$

The highstand systems tract consists of shoreface sandstones in all the wells in the study area, with the exception of Diamant-1 and Eg-1 in the westernmost part of the Heno Plateau, where deep erosion at $\mathrm{SB}_{2}$ is indicated.

The highstand systems tract on the Gertrud Plateau is characterised by a coarsening-upwards succession up to $70 \mathrm{~m}$ thick of intensely bioturbated siltstones and fineto medium-grained sandstones, deposited on the lower to middle shoreface (Gert-2, Jeppe-1, Gwen-2, Q-1; Fig. 5). The top of the systems tract is defined at the most coarse-grained part of the sandstones in Gert-2, and at the base of the conglomerate that caps the sandstones in the Jeppe-1, Gwen-2 and Q-1 wells (Figs 5, 9, 10). The conglomerate was probably deposited during relative sea-level fall and subsequent sea-level rise, as described earlier, and the base of the conglomerate is thus interpreted as a sequence boundary $\left(\mathrm{SB}_{2}\right.$; Fig. 5). Similarly, the highstand systems tract in the Ravn-1 well, on the Heno Plateau, is composed of a fine-grained, bioturbated shoreface sandstone unit, $2.3 \mathrm{~m}$ thick, capped by a $2 \mathrm{~m}$ thick conglomerate, the base of which defines $\mathrm{SB}_{2}$ (Figs $8,11,12$ ). In the $\mathrm{W}-1$ well, the top of the highstand systems tract is placed at the base of a conglomerate, the presence of which is inferred from the low gamma-ray readings and cuttings samples (Fig. 8).

In the basin areas (Tail End Graben, south-eastern Heno Plateau, Salt Dome Province), the highstand systems tract is $50-200 \mathrm{~m}$ thick and consists of a coarsening-upwards succession of clayey sediments. This suggests that the graben areas subsided at a higher rate than when the lowstand sediments of sequence 1 were deposited. Locating the upper sequence boundary $\left(\mathrm{SB}_{2}\right)$ in the basin areas is problematic. The rate of graben subsidence may have exceeded the rate of eustatic fall, such that sequence boundary $\mathrm{SB}_{2}$ is a correlative conformity; the sequence boundary would thus be placed at the most coarse-grained part of the lower shoreface sandstones, marking the maximum regression (Figs 8 , 13, 17A). Alternatively, if the shoreface sandstones in the basin areas were deposited during a relative fall in sea level, as suggested on the plateau areas, part of the sandy succession in Edna-1 may represent sediments of the lowstand systems tract (Fig. 17B). Following this line of reasoning, the sequence boundary should be placed beneath, or in the lowermost levels, of the coarsening-upwards shoreface sandstones (Fig. 17B). Unfortunately, the biostratigraphic, seismic and petrophysical data are ambiguous with respect to these two alternative interpretations; in this study, the first interpretation is preferred, i.e. the thick coarsening-upwards succession of shoreface sandstones is referred to the highstand systems tract (Figs 8, 17A).

The highstand systems tract in the Feda Graben is also characterised by a thick coarsening-upwards succession, 75-100 m thick, without notable breaks (Fig. 5). The lowermost part of the systems tract is more finegrained in the Feda Graben than in the Salt Dome Province; it comprises a basal unit of organic-rich offshore claystones overlain by claystones and siltstones, followed by very fine-grained lower shoreface sandstones (Fig. 5). In the Norwegian well, 2/12-7, farther out in the Feda Graben, the correlative section is $110 \mathrm{~m}$ thick and is composed of regressive offshore claystones and siltstones. Significant stratigraphic breaks have not been recognised and conglomerates are absent from the succession. The upper sequence boundary $\left(\mathrm{SB}_{2}\right)$ is placed at the most coarse-grained part of the lower shoreface sandstones, marking the maximum regression (Fig. 5). The conformable nature of $\mathrm{SB}_{2}$ in this area suggests that the subsidence rate of the Feda Graben was higher than the rate of eustatic sea-level fall such that fluvial/beach conglomerates did not prograde into the graben.

The conglomerates of the Gertrud Plateau (Jeppe-1 and Gwen-2) are thin and relatively fine-grained and probably represent a smaller fall in sea level than that suggested by the Ravn- 1 succession, where low rates of subsidence (or even uplift) may have enhanced the effect of a small eustatic sea-level fall. Conversely, high rates of subsidence on the Gertrud Plateau may have obscured significant eustatic sea-level fall. The shoreface sandstones prograded towards the east and north-east across the Heno Plateau and towards the west and south-west on the Gertrud Plateau (Figs 14E, 15; 16D). 
A

Plateau
Ravn-1
Edna-1

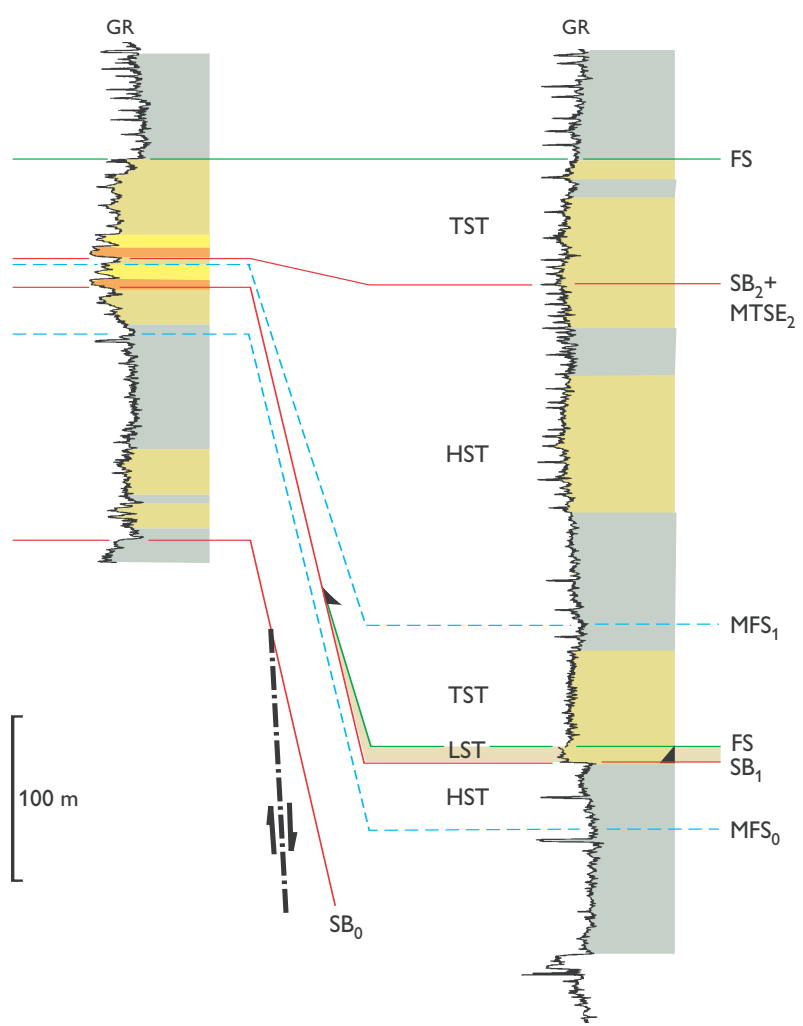

B

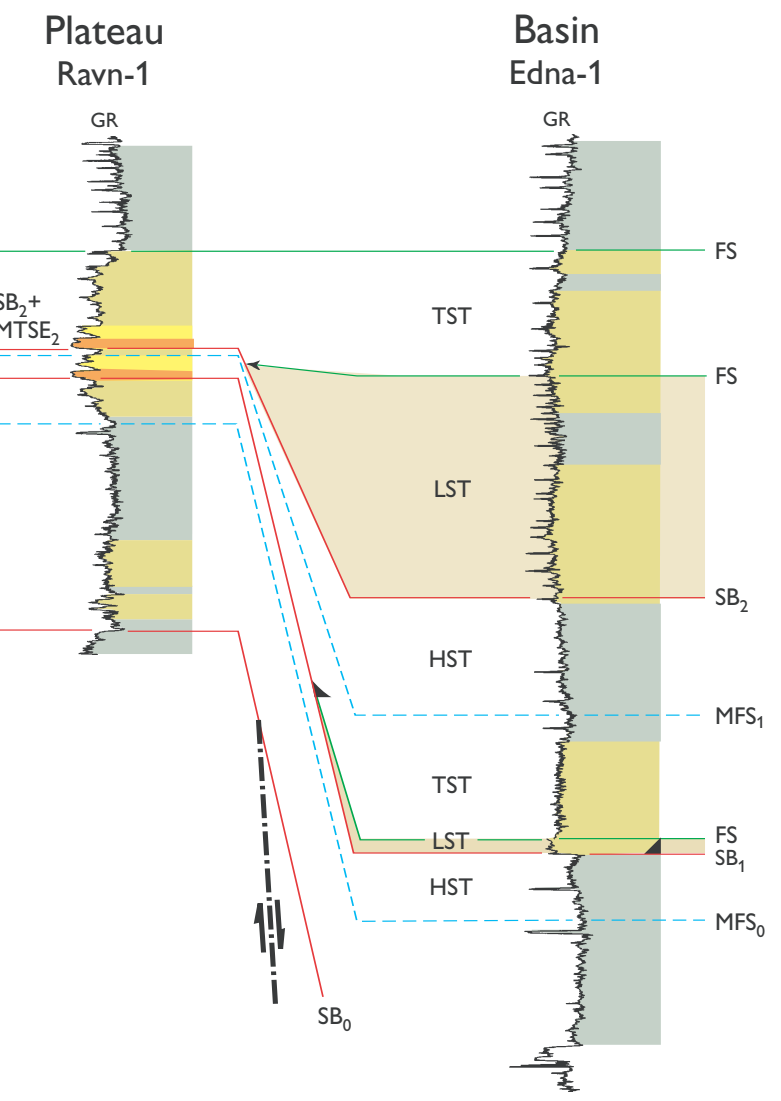

Fig. 17. Two alternative interpretations concerning the correlation of sequence boundary $\mathrm{SB}_{2}$ from the Heno Plateau (Ravn-1) to the Salt Dome Province (Edna-1); for legend, see Fig. 5. A: A fall in sea level is indicated on the Heno Plateau by the $2 \mathrm{~m}$ thick conglomerate that erosionally overlies fine-grained shoreface sandstones in the Ravn-1 well. No indication of this fall in sea level is evident in the basin (e.g. Edna-1). Consequently, the sequence boundary $\left(\mathrm{SB}_{2}\right)$ is correlated from the base of the conglomerate on the Heno Plateau to the most coarse-grained part of the lower shoreface sandstones, marking maximum regression in the basin. B: Alternatively, as discussed in the text, it can be argued that the correlative conformity $\left(\mathrm{SB}_{2}\right)$ should be placed at some point in the lower part of the coarsening-upwards shoreface sandstones. According to this interpretation, the coarsening-upwards lowstand systems tract represents sediments that bypassed the plateau areas.

\section{Sequence 2}

In sequence 2 , sandstones are only found in the transgressive systems tract (Figs 5, 8); the highstand systems tract consists solely of offshore claystones and shoreface siltstones and is not described further in this paper; for discussion of this succession, the reader is referred to Johannessen et al. (1996) and Andsbjerg \& Dybkjær (2003, this volume). Sequence 2 corresponds to the Kimm-3 sequence of Andsbjerg \& Dybkjær (2003, this volume).

\section{Transgressive systems tract}

Sediments of the transgressive systems tract are distributed throughout the study area. On the southern Heno Plateau, the sandstones of the transgressive systems tract form an aggrading to backstepping parasequence set ( $55 \mathrm{~m}$ thick in Ravn-1) composed of middle and lower shoreface sandstones; these are abruptly overlain by offshore claystones of the Farsund Formation (Figs $8,11,12$ ). The base of the offshore claystones represents a major flooding surface which can be traced 
all over the Gertrud Plateau and the northern, shallow part of the Heno Plateau (Figs 5, 8). This suggests that the plateaus were abruptly flooded, either due to a rapid rise in relative sea level or as a result of an abrupt shut-down in coarse clastic supply, due to submergence of highs that acted as sand source areas (Johannessen et al. 1996; Howell et al. 1996).

Over much of the Gertrud Plateau, the transgressive systems tract consists of backstepping middle shoreface sandstones (10-28 m thick) overlying the basal conglomerate (e.g. Gwen-2, Q-1, Jeppe-1; Fig. 5). The sandstones are directly overlain by offshore claystones of the Farsund Formation in all three wells and lower shoreface sandstones are not recognised, in contrast to wells of the Heno Plateau (Figs 5, 8).

In the Gert-2 well, however, on the westernmost part of the Gertrud Plateau close to the Feda Graben, an aggradational succession ( $43 \mathrm{~m}$ thick) composed of clayey, very fine-grained lower shoreface sandstones is referred to the transgressive systems tract (Fig. 5). The sandstones are abruptly overlain by offshore claystones indicating an overall deepening. The greater thickness and finer grain size in Gert-2 compared to the Jeppe-1, Gwen-2 and Q-1 wells suggests that the westernmost part of the Gertrud Plateau experienced higher subsidence rates than the rest of the plateau and that Gert-2 was situated more distally, relative to the other wells. The sedimentation rate in the westernmost part of the plateau must have been high to keep up with the continuously increasing accommodation space. This may have been the result of synsedimentary fault activity at the western border of the Gertrud Plateau (Johannessen et al. 1996).

In the Feda Graben, the transgressive systems tract consists of a fining-upwards succession of clayey very fine-grained, lower shoreface sandstones and offshore siltstones and claystones, as seen in the Gert-4 (60 m thick), 2/12-1 (45 m) and 2/11-7 (15 m) wells (Fig. 5). This fining-upwards transgressive succession is absent in the Gert-1 well, in the easternmost Feda Graben (Fig. 5); seismic data suggest that a normal fault may have cut out this part of the section in this well (Johannessen et al. 1996).

On the south-east Heno Plateau and in the Salt Dome Province, clayey, very fine-grained, lower shoreface sandstones, 30-60 m thick, gradually fine upwards into offshore claystones (Fig. 8). In the Diamant-1 well, on the westernmost part of the Heno Plateau near the Inge High, the uppermost portion $(10 \mathrm{~m})$ of the fine- to medium-grained upper shoreface sandstone succession overlying the conglomerate shows an overall fining- upwards, transgressive trend and is abruptly overlain by offshore claystones (Fig. 8). These sandstones represent the most permeable (1.2-2.7 Darcy) and most porous (22-30\%) Jurassic sandstones recorded in the Danish Central Graben.

In the Tail End Graben, the transgressive systems tract comprises fine-grained clay-rich sediments $(50 \mathrm{~m}$ thick in Nora-1); in the Feda Graben, this tract consists of a succession of clayey, very fine-grained sandstones and claystones, $80 \mathrm{~m}$ thick in Gert- 4 (Figs 5, 8, 13). The transgressive systems tract is thick and coarser on the Heno Plateau in Ravn-1 (55 m thick section of mediumto very fine-grained sandstones; Fig. 8) but is thinner, (c. $25 \mathrm{~m}$ thick) over the remaining part of the Heno Plateau. On the Gertrud Plateau, the transgressive systems tract is thin (10 $\mathrm{m}$ thick, fine-grained sandstone). The thin nature of the transgressive systems tract on the plateau areas compared with the graben areas suggests that the platform experienced a lower subsidence rate. The Heno and Gertrud Plateaus were transgressed from both the east and the west (Figs 14E-G, 15, 16E).

\section{Discussion}

The geometry of the depositional units and the interpreted palaeogeography indicate that the sandstones were sourced from the Mandal High, north-east of the Gertrud Plateau, and the Inge-Mads Highs west of the Heno Plateau, which formed part of the Mid North Sea High during the Kimmeridgian. The Gertrud and Heno Plateaus formed a contiguous area. Two grabens fringed the platform areas: the Feda Graben towards the northwest and the Tail End Graben towards the south-east.

\section{Graben versus plateau successions}

The identified sequences show major lateral differences from the plateaus to the grabens. On the shallow plateaus, the sequences are thin and more coarsegrained than in the adjacent grabens (Figs 5, 8, 13). The conglomerates that mark sequence boundaries $\mathrm{SB}_{1}$ and $\mathrm{SB}_{2}$ on the shallow Heno Plateau and $\mathrm{SB}_{2}$ on the Gertrud Plateau are not observed in the graben areas and the deeper, south-eastern portion of the Heno Plateau, indicating that the sea level did not fall to such a degree that rivers or beaches reached these areas. This was probably due to the higher rates of subsidence in the two grabens relative to the plateau areas. 
Two major sea-level falls were responsible for the formation of the conglomerates that mark sequence boundaries $\mathrm{SB}_{1}$ and $\mathrm{SB}_{2}$ on the Heno Plateau. On the deep, south-east Heno Plateau and in the Salt Dome Province, only $\mathrm{SB}_{1}$ is distinctly developed, being defined by the base of sharp-based lowstand shoreface sandstones. The succeeding sequence boundary $\mathrm{SB}_{2}$ is developed as a correlative conformity in the grabens. This suggests that the graben was subsiding at smaller rates during the fall in relative sea level responsible for $\mathrm{SB}_{1}$ than during the subsequent fall in relative sea level $\left(\mathrm{SB}_{2}\right)$.

The shoreface sandstones of the transgressive systems tract of sequence 2 in the graben areas gradually fine upwards and grade into the offshore claystones of the Farsund Formation. In contrast, shoreface sandstones on the plateau areas are abruptly overlain by offshore claystones indicating an abrupt cessation of supply of coarse sediment due to submergence of the source areas. The abrupt cessation of coarse sediment supply probably happened after deposition of the sandy sediments in the graben areas, since no abrupt decrease in grain-size is seen here.

\section{Potential distribution of reservoir sandstones}

The sequence stratigraphic interpretation presented here has implications for the potential distribution of sandstone reservoirs elsewhere in the northern Danish Central Graben, in areas that are presently undrilled.

\section{Incised valley fill}

During sea-level fall, rivers probably intersected previously deposited shoreface sandstones resulting in sediment transport across the Heno and Gertrud Plateaus and deposition basinward in the Tail End and Feda Grabens, on the south-east Heno Plateau and in the Salt Dome Province. During the subsequent transgression, high-energy shoreface processes removed all fluvial sediments on the plateaus, leaving only a transgressive lag behind, forming the most coarse-grained sediment resting upon the marine transgressive surfaces of erosion (MTSE). Where fluvial incision was sufficiently deep, however, incised valley fills may have been preserved, at least in part. Such inferred incised valleyfills, possibly comprising thick fluvial and estuarine coarse-grained sandstones with good reservoir properties, may represent an important exploration target.

\section{Lowstand shoreface sandstones}

The lowstand shoreface clayey sandstones of sequence 1 are only about $10 \mathrm{~m}$ thick on the south-east Heno Plateau and in the Salt Dome Province. Thicker, coarser and better-sorted shoreface sandstones may be found near the outer reaches of incised valleys, but have not yet been drilled. Such sandstones may constitute good reservoirs and are situated closer to the source rocks of the Farsund Formation in the Tail End Graben than the sandstones upon the plateaus.

The sea-level fall in the eastern part of the Feda Graben and the northern part of the Gertrud Plateau is represented by a bypass surface $\left(\mathrm{SB}_{1}\right)$ amalgamated with the 'base Jurassic' unconformity (Fig. 15). Lowstand shoreface sandstones are thus expected to be present farther out in the Feda Graben, as observed in the Tail End Graben.

\section{Stranded parasequences}

Between the plateau areas and the Tail End Graben and the south-eastern part of the Heno Plateau, stranded parasequences (the forced regressive systems tract of Hunt \& Tucker 1992, 1995) comprising shoreface sandstones may have been deposited if the sea-level fall occurred in steps. Such stranded parasequences may represent important future reservoir targets.

\section{Outer Rough Basin}

The shoreface 'Fife sandstones' of the Fife Field situated immediately north-west of the Danish Central Graben in the UK sector are very similar to those of the Heno Formation. The 'Fife sandstones' have been referred to the Early-Middle Volgian (Mackertich 1996) although a recent study suggested that they may extend down to the latest Kimmeridgian (Spathopoulos et al. 2000). Thus, although limited temporal overlap is possible, these sands are mostly younger than the Upper Kimmeridgian Heno Formation deposited on the plateaus to the east of the Mads and Inge Highs. It is likely, therefore, that Volgian shoreface sandstones were also deposited in Danish territory just east of the Mid North Sea High along the western flank of the Outer Rough Basin (Fig. 1). The shoreface sandstones may have been trapped due to rotation of the Outer Rough Basin during the Early-Middle Volgian. 


\section{Sand deposited by tidal currents?}

During the Kimmeridgian, the marine embayments formed by the Tail End and Feda Grabens were at times separated by land and at other times connected by shallow seas upon the intervening structural highs (Fig. 14). During periods of shallow submersion, the sandy plateau between the Tail End and Feda Grabens may have been swept by tidal currents as water masses were transported from one basin to the other over the submarine plateau. The width of the passage over the submarine plateau from the Mandal High to the Inge High was probably about $35-40 \mathrm{~km}$. It is likely, therefore, that some of the sandstones of the Heno Formation were deposited or redeposited by tidal currents although investigation of the importance of tidal processes in this setting is precluded by the pervasive bioturbation and the resultant scarcity of primary sedimentary structures. Tidal sediments have been reported from broadly equivalent strata in the UK sector, both from the nearby Fife and Angus Fields (Spathopoulos et al. 2000) and from the Fulmar Formation farther north-west (Howell et al. 1996). The former authors also described facies in the 'Fife sandstones' that were interpreted as the deposits of high density flows, either induced by storms or representing turbiditic flows derived from a nearby structural high.

\section{Acknowledgements}

The present paper is part of a Ph.D. thesis, supported financially by the Geological Survey of Denmark and the Ministry of Energy (ENS No. 1313/92-0002) and supervised by Finn Surlyk, University of Copenhagen. Finn Surlyk is thanked for his penetrative, constructive comments on the paper and improvement of the English. Ron Steel and Alf Ryseth reviewed the paper and are thanked for many helpful comments, which greatly improved the quality of the manuscript. The editorial work by Jon R. Ineson is very much appreciated. Lars Henrik Nielsen, Jon R. Ineson, Jan Andsbjerg and Karen Dybkjær at GEUS are thanked for fruitful and stimulating discussions.

\section{References}

Andsbjerg, J. 2003: Sedimentology and sequence stratigraphy of the Bryne and Lulu Formations, Middle Jurassic, northern Danish Central Graben. In: Ineson, J.R. \& Surlyk, F. (eds): The
Jurassic of Denmark and Greenland. Geological Survey of Denmark and Greenland Bulletin 1, 301-347 (this volume).

Andsbjerg, J. \& Dybkjær, K. 2003: Sequence stratigraphy of the Jurassic of the Danish Central Graben. In: Ineson, J.R. \& Surlyk, F. (eds): The Jurassic of Denmark and Greenland. Geological Survey of Denmark and Greenland Bulletin 1, 265-300 (this volume).

Armstrong, L.A., Ten Haven, A. \& Johnson, H.D. 1987: The geology of the Gannet fields, central North Sea, UK sector. In: Brooks, J. \& Glennie, K.W. (eds): Petroleum geology of North West Europe, 533-548. London: Graham \& Trotman.

Bergan, M., Tørudbakken, B. \& Wandås, B. 1989: Lithostratigraphic correlation of Upper Jurassic sandstones within the Norwegian Central Graben: sedimentological and tectonic implications. In: Collinson, J.D. (ed.): Correlation in hydrocarbon exploration, 243-251. London: Graham \& Trotman for the Norwegian Petroleum Society (NPF).

Bromley, R.G. 1990: Trace fossils: biology and taphonomy. Special topics in Palaeontology 3, 280 pp. London: Unwin Hyman.

Damtoft, K., Nielsen, L.H., Johannessen, P.N., Thomsen, E. \& Andersen, P.R. 1992: Hydrocarbon plays of the Danish Central Trough. In: Spencer, A.M. (ed.): Generation, accumulation and production of Europe's hydrocarbons II. European Association of Petroleum Geoscientists Special Publication 2, 35-58.

Donovan, A.D., Djakic, A.W., Ioannides, N.S., Garfield, T.R. \& Jones, C.R. 1993: Sequence stratigraphic control on Middle and Upper Jurassic reservoir distribution within the UK Central North Sea. In: Parker, J.R. (ed.): Petroleum geology of Northwest Europe: proceedings of the 4th conference, 251-269. London: Geological Society.

Eynon, G. 1981: Basin development and sedimentation in the Middle Jurassic of the northern North Sea. In: Illing, L.V. \& Hobson, G.D. (eds): Petroleum geology of the continental shelf of North-West Europe: proceedings of the 2nd conference, 196-204. London: Heyden \& Son Ltd.

Frey, R.W. \& Pemberton, S.G. 1985: Biogenic structures in outcrops and cores. I. Approaches to ichnology. Bulletin of Canadian Petroleum Geology 33, 72-115.

Gawthorpe, R.L., Fraser, A.J. \& Collier, R.E.L. 1994: Sequence stratigraphy in active extensional basins: implications for interpretation of ancient basin-fills. Marine and Petroleum Geology 11, 642-658.

Hansley, P.L. \& Whitney, C.G. 1990: Petrology, diagenesis, and sedimentology of oil reservoirs in Upper Cretaceous Shannon Sandstone beds, Powder River basin, Wyoming. United States Geological Survey Bulletin 1917C, 33 pp.

Helland-Hansen, W. \& Gjelberg, J.G. 1994: Conceptual basis and variability in sequence stratigraphy: a different perspective. Sedimentary Geology 92, 31-52.

Howell, J.A., Flint, S.S. \& Hunt, C. 1996: Sedimentological aspects of the Humber Group (Upper Jurassic) of the South Central Graben, UK North Sea. Sedimentology 43, 89-114.

Hunt, D. \& Tucker, M.E. 1992: Stranded parasequences and the forced regressive wedge systems tract: deposition during baselevel fall. Sedimentary Geology 81, 1-9.

Hunt, D. \& Tucker, M.E. 1995: Stranded parasequences and the forced regressive wedge systems tract: deposition during the 
base-level fall - reply. Sedimentary Geology 95, 147-160.

Japsen, P., Britze, P. \& Andersen, C. 2003: Upper Jurassic - Lower Cretaceous of the Danish Central Graben: structural framework and nomenclature. In: Ineson, J.R. \& Surlyk, F. (eds): The Jurassic of Denmark and Greenland. Geological Survey of Denmark and Greenland Bulletin 1, 233-246 (this volume).

Jensen, T.F., Holm, L., Frandsen, N. \& Michelsen, O. 1986: Jurassic - Lower Cretaceous lithostratigraphic nomenclature for the Danish Central Trough. Danmarks Geologiske Undersøgelse Serie A 12, 65 pp.

Johannessen, P.N. 1995: Genetic stratigraphy of shallow marine and paralic deposits: Upper Jurassic, Danish Central Graben; Upper Cretaceous, San Juan Basin, New Mexico; and Lower Jurassic, Bornholm, Baltic Sea 1-4, 107 pp. (parts paginated separately). Unpublished Ph.D. thesis, University of Copenhagen, Denmark.

Johannessen, P.N. \& Andsbjerg, J. 1993: Middle to Late Jurassic basin evolution and sandstone reservoir distribution in the Danish Central Trough. In: Parker, J.R. (ed.): Petroleum geology of Northwest Europe: proceedings of the 4th conference, 271-283. London: Geological Society.

Johannessen, P.N., Dybkjær, K. \& Rasmussen, E.S. 1996: Sequence stratigraphy of Upper Jurassic reservoir sandstones in the northern part of the Danish Central Trough, North Sea. Marine and Petroleum Geology 13, 755-770.

Johnson, H.D., Mackay, T.A. \& Stewart, D.J. 1986: The Fulmar oil-field (Central North Sea): geological aspects of its discovery, appraisal and development. Marine and Petroleum Geology 3, 99-125.

Koch, J.-O. 1983: Sedimentology of Middle and Upper Jurassic sandstone reservoirs of Denmark. In: Kaasschieter, J.P.H. \& Reijers, T.J.A. (eds): Petroleum geology of the southeastern North Sea and the adjacent onshore areas. Geologie en Mijnbouw 62, 115-129.

Mackertich, D. 1996: The Fife Field, UK Central North Sea. Petroleum Geoscience 2, 373-380.

Michelsen, O., Frandsen, N., Holm, L., Jensen, T.F., Møller, J.J. \& Vejbæk, O.V. 1987: Jurassic - Lower Cretaceous of the Danish Central Trough; - depositional environments, tectonism, and reservoirs. Danmarks Geologiske Undersøgelse Serie A 16, $45 \mathrm{pp}$.

Michelsen, O., Nielsen, L.H., Johannessen, P.N., Andsbjerg, J. \& Surlyk, F. 2003: Jurassic lithostratigraphy and stratigraphic development onshore and offshore Denmark. In: Ineson, J.R. \& Surlyk, F. (eds): The Jurassic of Denmark and Greenland. Geological Survey of Denmark and Greenland Bulletin 1, 147-216 (this volume)

Møller, J.J. \& Rasmussen, E.S. 2003: Middle Jurassic - Early Cretaceous rifting of the Danish Central Graben. In: Ineson, J.R. \& Surlyk, F. (eds): The Jurassic of Denmark and Greenland. Geological Survey of Denmark and Greenland Bulletin 1, 247-264 (this volume).

Noe-Nygaard, N., Surlyk, F. \& Piasecki, S. 1987: Bivalve mass mortality caused by toxic dinoflagellate blooms in a Berriasian-Valanginian lagoon, Bornholm, Denmark. Palaios 2, 263-273.

Odin, G.S. \& Fullagar, P.D. 1988: Geological significance of the glaucony facies. In: Odin, G.S. (ed.): Green marine clays, 295-332. Amsterdam: Elsevier.

Partington, M.A., Copestake, P., Mitchener, B.C. \& Underhill, J.R. 1993: Biostratigraphic calibration of genetic stratigraphic sequences in the Jurassic - lowermost Cretaceous (Hettangian to Ryazanian) of the North Sea and adjacent areas. In: Parker, J.R. (ed.): Petroleum geology of Northwest Europe: proceedings of the 4th conference, 371-386. London: Geological Society.

Pemberton, S.G., MacEachern, J.A. \& Frey, R.W. 1992: Trace fossil facies models: environmental and allostratigraphic significance. In: Walker, R.G. \& James, N.P. (eds): Facies models: response to sea level change, 47-72. Ontario: Geological Association of Canada.

Plint, A.G. 1988: Sharp-based shoreface sequences and 'offshore bars' in the Cardium Formation of Alberta; their relationship to relative changes in sea level. In: Wilgus, C.K. et al. (eds): Sea-level changes - an integrated approach. Society of Economic Paleontologists and Mineralogists Special Publication 42, 357-370.

Posamentier, H.W. \& Vail, P.R. 1988: Eustatic controls on clastic deposition II - sequence and systems tract models. In: Wilgus, C.K. et al. (eds): Sea-level changes - an integrated approach. Society of Economic Paleontologists and Mineralogists Special Publication 42, 125-154.

Price, J., Dyer, R., Goodall, I., McKie, T., Watson, P. \& Williams, G. 1993: Effective stratigraphical subdivision of the Humber Group and the Late Jurassic evolution of the UK Central Graben. In: Parker, J.R. (ed.): Petroleum geology of Northwest Europe: proceedings of the 4th conference, 443-458. London: Geological Society.

Rasmussen, E.S. 1995: Structural evolution of the Gert-Mjølner area. Marine and Petroleum Geology 12, 377-385.

Rattey, R.P. \& Hayward, A.B. 1993: Sequence stratigraphy of a failed rift system: the Middle Jurassic to Early Cretaceous basin evolution of the Central and Northern North Sea. In: Parker, J.R. (ed.): Petroleum geology of Northwest Europe: proceedings of the 4th conference, 215-249. London: Geological Society.

Richards, P.C., Lott, G.K., Johnson, H., Knox, R.W.O'B. \& Riding, J.B. 1993: Jurassic of the Central and Northern North Sea. In: Knox, R.W.O'B. \& Cordey, W.G. (eds): Lithostratigraphic nomenclature of the UK North Sea 3, 219 pp. Nottingham: British Geological Survey.

Seilacher, A. 1967: Bathometry of trace fossils. Marine Geology 5, 413-428.

Smelror, M. \& Leereveld, H. 1989: Dinoflagellate and acritarch assemblages from the Late Bathonian to Early Oxfordian of Montagne Crussol, Rhone Valley, southern France. Palynology 13, 121-141.

Söderström, B., Forsberg, A., Holtar, E. \& Rasmussen, B.A. 1991: The Mjølner Field, a deep Upper Jurassic oil field in the Central North Sea. First Break 9, 156-171.

Spathopoulos, F., Doubleday, P.A. \& Hallsworth, C.R. 2000: Structural and depositional controls on the distribution of the Upper Jurassic shallow marine sandstones in the Fife and Angus fields area, Quadrants 31 \& 39, UK Central North Sea. 
Marine and Petroleum Geology 17, 1053-1082.

Taylor, A.M. \& Gawthorpe, R.L. 1993: Application of sequence stratigraphy and trace fossil analysis to reservoir description: examples from the Jurassic of the North Sea. In: Parker, J.R. (ed.): Petroleum geology of Northwest Europe: proceedings of the 4th conference, 317-335. London: Geological Society. Van Wagoner, J.C., Mitchum, R.M., Campion, K.M. \& Rahmanian, V.D. 1990: Siliciclastic sequence stratigraphy in well logs, cores, and outcrops: concepts for high-resolution correlation of time and facies. American Association of Petroleum Geologists, Methods in Exploration Series 7, 55 pp.
Vollset, J. \& Doré, A.G. (eds) 1984: A revised Triassic and Jurassic lithostratigraphic nomenclature for the Norwegian North Sea. Norwegian Petroleum Directorate Bulletin 3, 53 pp.

Wakefield, L.L., Droste, H., Giles, M.R. \& Janssen, R. 1993: Late Jurassic plays along the western margin of the Central Graben. In: Parker, J.R. (ed.): Petroleum geology of Northwest Europe: proceedings of the 4th conference, 459-468. London: Geological Society.

Walker, R.G. \& Bergman, K.M. 1993: Shannon Sandstone in Wyoming: a shelf-ridge complex reinterpreted as lowstand shoreface deposits. Journal of Sedimentary Petrology 63 , 839-851.

Manuscript received 28 November 1995; revision accepted 15 January 2000. 